\title{
“Atatürkçülük” Kavramına İlişkin Sosyal Bilgiler Öğretmen Adaylarının Metaforik Algıları
}

\author{
Melike Faiz ${ }^{* *}$, Emine Karasu Avci****
}

Makale Geliş Tarihi: 26.10.2018

Makale Kabul Tarihi:26.02.2019

DOI: $10.35675 /$ befdergi. 475283

$\ddot{O} z$

Atatürkçülük kavram olarak Mustafa Kemal Atatürk'ün düşüncelerinin takipçisi olma anlamını içeren, Atatürk milliyetçiliğine bağlı, belirli bir sınıfa ait olmayan aklı ve bilimi önde tutan ideolojidir. Atatürkçü ideolojinin temelini, Mustafa Kemal Atatürk'ün düşünceleri ve uygulamalarıyla ortaya koyduğu amaçlar, ilkeler ve gerçekleştirdiği yenilikler oluşturur. Atatürkçülük, Türk tarihinden, Türk vatanının sahip olduğu kaynaklardan ve Türk insanının isteklerine çare bulma ihtiyacından doğmuştur. Bu araştırmada, Sosyal Bilgiler öğretmen adaylarının Atatürkçülük kavramına ilişkin metaforik algıları incelenmiştir. Araştırma fenomenoloji olarak desenlenmiştir. Araştırmanın çalışma grubunu 208 Sosyal Bilgiler ögretmen adayı oluşturmaktadır. Araştırmada veriler öğretmen adaylarından "Atatürkçülük ... gibidir. Çünkü ... .” cümlesini tamamlamalart istenerek elde edilmiştir. Elde edilen veriler içerik analiz yoluyla çözümlenmiştir. Araştırmada en çok üzerinde durulan metaforlar güneş, özgürlük, ağaç, vatanseverlik, hayat, devrim, su ve bayrak metaforlarldır. En fazla metafor geliştirilen kategoriler ise aydınlatıcı ve yol gösterici olarak Atatürkçülük ile gereklilik ve zorunluluk olarak Atatürkçülük kategorileridir.

Anahtar Kelimeler: Atatürkçülük, metafor, ögretmen adayl, Sosyal Bilgiler.

\section{The Metaphorical Perceptions of Social Studies Teacher Candidates Related to "Ataturkism"}

\section{Abstract}

Ataturkism is a ideology that is based on Atatürk's nationalism, which means to be a follower of Mustafa Kemal Ataturk's thoughts, and which does not belong to a particular class, and keeps intelligence and knowledge ahead. The foundations of Atatürkist ideology are the aims, principles and innovations that Mustafa Kemal Atatürk put forward with his thoughts and practices. Ataturkism is born of the Turkish history and the sources of the Turkish homeland and the need to remedy the needs of the Turkish people. In this research, the perceptions of Metaforth of Social Studies teacher candidates regarding the concept of Ataturkism were examined. Phenomenology design is used in this research. The study group of the study is composed of 208 social science teacher candidates. Teacher candidates given

\footnotetext{
* Bu çalışma 2. Uluslararası Avrasya Sosyal Bilimler Kongresinde “““Atatürkçülük” Kavramına İlişkin Sosyal Bilgiler Öğretmen Adaylarının Metaforları adlı sözlü bildirinin çalışma grubu genişletilmiş halidir. ** Kastamonu Üniversitesi, Eğitim Fakültesi, Türkçe ve Sosyal Bilimler Eğitimi Bölümü, Kastamonu, Türkiye, melikefaiz@ gmail.com, ORCID: 0000-0001-8070-6086

*** Kastamonu Üniversitesi, Eğitim Fakültesi, Türkçe ve Sosyal Bilimler Eğitimi Bölümü, Kastamonu, Türkiye, eavci@kastamonu.edu.tr, ORCID: 0000-0002-3135-2557
}

Kaynak Gösterme: Faiz, M. ve Karasu-Avcı, E. (2019). “Atatürkçülük” kavramına ilişkin sosyal bilgiler öğretmen adaylarının metaforik algıları. Bayburt Eğitim Fakültesi Dergisi, 14(28), 217-252. https://doi.org/10.35675/befdergi.475283 
in the survey are asked to complete the statement "Ataturkism ... is like. Because ... ". The obtained data were analyzed by content analysis. The most discussed metaphors in the study are sun, freedom, tree, patriotism, life, revolution, water and flag metaphor. The categories with the most metaphor developed are the Ataturkism as the enlightening and guiding and the Ataturkism as the necessity and necessity.

Keywords: Ataturkism, metaphor, candidate teacher, social studies.

\section{Giriş}

I. Dünya Savaşı'ndan yenik olarak ayrılan Osmanlı Devleti, Anlaşma Devletleri tarafından yok sayılmış ve tarihten silinmek istenmiştir. Mustafa Kemal Atatürk, Türk milleti için kritik olan bu zaman diliminde Kurtuluş Savaşı'na millilik ve meşruluk kazandırarak tüm dünya için örnek bir bağımsızlık savaşının lideri olmuştur. Türkiye Cumhuriyeti Devleti'nin milli ve üniter bir devlet olarak temellerinin atılmasını ve bağımsızlık savaşının kazanılmasını sağlamıştır (Kayıran ve Metintaş, 2013). Atatürk yalnızca Türk milleti için değil sömürülen tüm milletlerde bağımsızlık mücadelesi verilmesinin de bir örneğidir (Küçükmeriç, 1985). Bu anlamda Atatürk bağımsızlık ve özgürlüğün bir simgesi haline gelmiştir.

Atatürk, ülkemiz için batının bilim ve teknolojisini örnek alarak çağdaşlaşmanın yolunu açmış ve bir dizi inkılabı hayata geçirmiştir. Atatürk'ün inkılaplarını hayata geçirmede izlediği bu yol ve yöntemler "Atatürkçülük" olarak adlandırılmıştır (Kayıran ve Metintaş, 2013). Atatürkçülük, yeni kurulan Türkiye Cumhuriyeti’nin kuruluş felsefesidir (Öksüz, 2006). Atatürkçülük sadece Türk ülkesinin yok olma tehlikesine karşı ortaya çıkan bir eylem değildir; aynı zamanda bir düşünce sistemidir. Geçmişten günümüze kadar uzanan bir anlayıştır. Güncel problemlerin çözümünde yararlanılabilecek yol, yöntem ve inanç sistemidir (Özüçetin, 2005). Bu anlamda Atatürkçülük bir gereksinim ve ihtiyaç olarak ortaya çıkmıştır. Temelleri tam bağımsızlığa, ulusal egemenliğe, akıl ve bilimin yol göstericiliğine ve çağdaş uygarlık düzeyine ulaşma hedeflerine dayanmaktadır (Güler, tarihsiz). Türk milletinin tam bağımsızlığa ve milli egemenliğe dayanan bir yönetim sistemine sahip olması, çağdaş uygarlık düzeyine çıkmayı hedeflemesi ve Atatürk’ün ortaya koyduğu tüm ilkeler Atatürkçülük olarak tanımlanabilir (Dayı, 2003). Atatürkçülük, toplumsal hayatın her alanında bir değişim ve dönüşüm modelidir (Güler, tarihsiz). Katı ideolojik ve dogmatik düşüncelere karşı çıkıştır (Cihan, 1981). Türk milleti için yeni bir değerler sistemi ve hayat tarzıdır. Bu değerler sitemi, Atatürk'ün çağdaşlaşma yolunda yaptığı inkılaplarla birlikte Türk milletinin tarih boyunca geçirdiği deneyimler ve kazanımlardır (Keskin, 2004).

Atatürkçü dünya görüşü hem milli karakterlidir hem de hümanisttir. Milli karakterlidir; çünkü Türkiye Cumhuriyeti Devleti'nin fikir olarak ortaya çıkmasının ve kuruluşunun temelinde milliyetçilik yatmaktadır (Keskin, 2004). Mustafa Kemal Atatürk'ün 19 Mayıs 1919'da Samsun'a çıktığında yeni bir Türk Devleti kurma fikrini hayata geçirmeye çalışması Atatürkçü düşünce yapısının milli bir karaktere 
sahip olduğunu göstermektedir (Kayıran ve Metintaş, 2013). Dayı (2003) Türkiye Cumhuriyeti'nin Türk milletinin gerçeklerinden ortaya çıkan milli düşüncenin eseri olduğunu belirtmektedir. Atatürkçülük insan sevgisine dayalıdır (Özüçetin, 2005). İnsan sevgisi, insana ve onun yaşamına değer vermektir (Küçükmeriç, 1985). Atatürk kişisel hak ve özgürlüklere önem vermiş, eşitliği temel ilke edinmiştir. 1926 yılında medeni kanunun kabulü ile 1934'te kadınlara seçme ve seçilme hakkının verilmesi bunun en güzel örneği olarak değerlendirilebilir.

Atatürkçülük demokratik ve eşitlikçi bir yapıya sahiptir. Türkiye Büyük Millet Meclisi'nin 23 Nisan 1920'de açılması ile birlikte halkın egemenliğine dayanan demokratik bir yönetim anlayışı hayata geçirilmiştir (Keskin, 2004; Coşgun ve Zarpl1, 2015). Demokratik yönetim anlayışı eşitliği öngörmektedir. Atatürkçü düşüncenin eşitlik anlayışının en güzel örneği kadınlara tanıdığı hak ve özgürlüklerdir. Atatürk, Türk kadınının fedakârlıklarına yakından tanık olmuş bir lider olarak kadın ve erkek ayrımını kaldırmıştır. Kadınlara; eğitimde, hukukta, siyasette ve toplumsal alanda eşitlik tanımıştır. Bugün toplumsal hayatın her alanında yer alan kadınlar bunu Atatürk'e borçludurlar (Korkmaz, tarihsiz).

Atatürkçülük akıl ve bilime dayalıdır. Dünyadaki gelişmelere ayak uydurabilmek ancak akıl ve bilimle mümkündür. Kayıran ve Metintaş (2013) çağdaş uygarlık düzeyine ulaşabilme hedefinin akıl ve bilimle gerçekleşeceğini öngörmektedirler. Atatürk'e göre hayatta en iyi yol gösterici akıl, mantık ve bilimdir. Bu sayede gerçeklerle daha kolay yüzleşilebilir ve sorunların üstesinden gelinebilir (Korkmaz, tarihsiz). Atatürk toplumların gelişiminde bilimin ve bilimsel düşünmenin rolünün ne kadar önemli olduğunu hep vurgulamıştır. Atatürk'ün gerçekçiliğinin altında bilimsel düşünme becerisi yatmaktadır. Yaptığı inkılapların temelinde akıl ve bilim vardır. Bilim insanlarına yaklaşımı ve onlara verdiği değer de Atatürk'ün bilim ve aklı ne kadar önemsediğini ortaya koymaktadır (Erdem, 2014). Cumhuriyetin ilk yıllarında eğitimden ekonomiye, sanattan teknolojiye kadar toplumsal hayatın her alanında gerçekleştirilen değişimler ve dönüşümler bilimsel bir anlayışla ele alınmıştır. Kurultayların ve kongrelerin düzenlenmesi ile yurtdışından bilim insanlarının getirilmesi bilim ve akla verilen önemin bir göstergesidir (Kayadibi, 2006).

Atatürkçülük barışçıl bir felsefeye dayanır. Başta kendi toplumumuz ve ülkemizin daha sonra da tüm insanlığın gelişmesi ve ilerlemesini içerir. Bir dünya medeniyetinin oluşturulabilmesi için barış önemli bir yer teşkil eder (Keskin, 2004). Atatürkçü düşüncede barış, birleştirici ve bütünleştirici bir etkiye sahiptir (Küçükmeriç, 1985; Kayıran ve Metintaş, 2013). Türkiye Cumhuriyeti'nin geleceğe taşınmasında insanlar arasındaki uyum ve işbirliği ancak barışın sağlanmasıyla oluşmaktadır. Türk milletinin Kurtuluş Savaşı'nın temel amacı da başta kendi ülkemizde sonra da dünya devletleri ile barışı sağlayabilmektir. Atatürk uluslararası ilişkilerde anlaşmazlıkların barışçl yollarla çözümünü öngörmüştür. Zor durumda kalmadıkça kuvvete başvurmanın gereksiz olduğunu belirtmiştir (Dinç, 2008). O, iç 
barışın tüm insanlığın mutluluğu ve huzuru için dış barışla tamamlanmasının gerekli olduğuna inanmıştır (Korkmaz, tarihsiz). Mustafa Kemal Atatürk barışçıl dünya görüşünü Nutuk (2006)'ta şu şekilde dile getirmektedir:

"Türk milletini, uygarlık dünyasında, kendisine yaraşan konuma yükseltmek ve Türk Cumhuriyeti’ni sarsılmaz temelleri üzerinde her gün, daha çok güçlendirmek... ve bunun içinde zorbalık düşüncesini öldürmek..."

Atatürkçülük ile ilgili alanyazına bakıldığında yapılan çalışmaların çoğu literatür taraması şeklindedir. Daha çok Atatürkçülüğün ne olduğu, bireylerin ve gençlerin Atatürkçülüğ̈̈ nasıl algıladığı, Atatürk ve eğitim konularına değinen (Güler, tarihsiz; Küçükmeriç, 1985; Ertuğrul, 1988; Kocatürk, 1988; Akçakayalıŏlu, 1989; Ertuğrul, 1989; Başak, 2003; Centel, 2006; Dönmez, 2005; Dönmez, 2006a; Hic, 2008; Kayıran ve Yeşiltaş, 2013); değer eğitiminde Atatürk'ten tarihi kahraman olarak yararlanılması (Dönmez, 2006b) ve Atatürk'ün eğitim politikaları üzerinde duran çalışmalara (Polat, 1989) rastlanmaktadır. Alanyazında Atatürkçülüğün ne olduğu sıkça tartışılmış ve tanımı yapılmaya çalışılmıştır. Fakat bu konuda alanyazında eğitim araştırması azınlıktadır. Atatürkçülük kavramı ile ilgili görülen bu eksiklik bu araştırmanın yapılmasına ön ayak olmuştur. Atatürkçülük ve konularının ilkokul ve ortaokullarda en uygun verilebilecek derslerden birisi ve belki de en önemlisi Sosyal Bilgiler dersidir. Sosyal Bilgiler dersi, Sosyal Bilgiler öğretmenleri tarafından okutulmaktadır. Bu nedenle dersi okutacak ve geleceğin öğretmeni olacak Sosyal Bilgiler öğretmen adaylarının Atatürkçülük kavramına yönelik algılarının nasıl olduğu bu araştırmanın konusunu oluşturmaktadır. $\mathrm{Bu}$ doğrultuda araştırmada şu sorulara cevap aranmıştır:

- Sosyal Bilgiler öğretmen adaylarının "Atatürkçülük” kavramına iliş̧kin algiları nelerdir?

- 1.sınıf Sosyal Bilgiler öğretmen adaylarının "Atatürkçülük" kavramına ilişkin metaforları nelerdir?

- 2.sınıf Sosyal Bilgiler öğretmen adaylarının “Atatürkçülük” kavramına ilişkin metaforları nelerdir?

- 3.sınıf Sosyal Bilgiler öğretmen adaylarının "Atatürkçülük” kavramına ilişkin metaforları nelerdir?

- 4.sınıf Sosyal Bilgiler öğretmen adaylarının "Atatürkçülük” kavramına ilişkin metaforları nelerdir?

\section{Yöntem}

\section{Araştırma Modeli}

Araştırmada nitel araştırma türlerinden biri olan fenomenoloji deseni kullanılmıştır. Fenomenoloji, özel bir olgu üzerine, bağımsız katılımcılarla, görüşme yapılmasıyla toplanan veriler doğrultusunda onların görüşlerindeki ortak yönler tespit edilerek katılımcıların deneyimlerini ortaya koyan yöntem olarak açıklanmaktadır (Büyüköztürk, Kılıç Çakmak, Akgün, Karadeniz ve Demirel, 2012). Bu araştırmada 
da tarihi kahramanların değer eğitiminde kullanılmasına yönelik Sosyal Bilgiler öğretmen adaylarının deneyimlerinden faydalanıldığı için bu yöntem tercih edilmiştir.

\section{Çalışma Grubu}

Araştırmada çalışma grubu oluşturulurken kolay ulaşılabilir örneklem türü seçilmiştir. $\mathrm{Bu}$ örnekleme yöntemi araştırmacıya hız ve pratiklik kazandırması, yakın ve erişilmesi kolay olan bir çalışma grubunun seçilebilmesine imkan verir (Şimşek ve Yıldırım, 2011). Araştırmanın çalışma grubunu, 2017-2018 eğitimöğretim yılı güz yarıyılında bir devlet üniversitesinin Sosyal Bilgiler Öğretmenliği Lisans Programı'nda öğrenim görmekte olan ve araştırmaya gönüllü olarak katılmayı kabul eden 202öğretmen adayı oluşturmaktadır.Öğretmen adayları 1.,2., 3. ve 4.sınıflardan seçilmiştir. Aşağıdaki tabloda araştırmaya katılan Sosyal Bilgiler öğretmen adaylarının frekans ve yüzdelerini görebilirsiniz.

Tablo 1.

Sosyal Bilgiler Öğretmen Adaylarının Demografik Bilgilerine İlişkin Frekans ve

\begin{tabular}{rlllllll}
\hline \multicolumn{2}{l}{ Sinıf Düzeyi } & \multicolumn{5}{c}{ Frekans } & \multicolumn{5}{c}{ Yüzde } \\
\cline { 3 - 8 } & & K & E & Toplam & K & E & Toplam \\
\hline 1. & Sınıf & 29 & 25 & 54 & 53,7 & 46,2 & 100 \\
2. & Sinıf & 27 & 29 & 56 & 48,2 & 51,7 & 100 \\
3. & Sinıf & 30 & 21 & 51 & 58,8 & 41,1 & 100 \\
4. & Sinıf & 22 & 19 & 41 & 53,6 & 46,3 & 100 \\
Toplam & 108 & 94 & 202 & 53,4 & 46,5 & 100 \\
\hline
\end{tabular}

Yüzde Dă̆llımları

Tablo 1.'e göre araştırmaya katılan öğretmen adayları sırasıyla 1.sınıf ( $\mathrm{f}=54)$, $2 . \operatorname{sinıf}(f=56), 3$.sınıf $(f=51)$ ve 4.sınıf $(f=41)$ öğretmen adaylarıdır. Ayrıca araştırmaya katılan öğretmen adaylarının çoğunluğunu kadın öğretmen adayları ( $\mathrm{f}=108)$ oluşturmaktadır.

\section{Verilerin Toplanması}

Bu araştırmada veri toplama aracı olarak öğretmen adaylarının "Atatürkçülük ... gibidir. Çünkü ... .” cümlesini tamamlamaları istenmiştir. Öğretmen adaylarının cümleyi tamamlayabilmeleri için yeterince düşünebilecekleri süre $(5-10 \mathrm{dk}$.) tanınmıştır. Öğretmen adaylarından toplam 228 adet geri dönüt alınmıştır. 26 öğretmen adayının cevapları, sınıf düzeylerini, cinsiyetleri belirtmedikleri için ve 
bazıları da birden fazla metafor ürettikleri için geçersiz sayılmıştır. 202 öğretmen adayından elde edilen veriler ise geçerli sayılmıştır. Toplanan bu belgeler araştırmanın temel veri kaynağını oluşturmuştur. Araştırmada "çünkü" kavramına yer verilerek öğretmenlerin kendi metaforları için bir gerekçe oluşturmaları istenmiştir. Öğretmen adaylarının verdikleri cevaplar araştırmacılar tarafından gizli tutulmuş ve kimseyle paylaşılmamıştır.

\section{Verilerin Analizi ve Yorumlanması}

Araştırmada elde edilen veriler içerik analizi ile çözümlenmiştir. İçerik analizi, sosyal bilimlerde sıklıkla kullanılmakta olan analiz yöntemlerinden birisidir. İçerik analizi, metin ya da metinlerden meydana gelen araştırma konusunun kelimeler, kelime öbekleri ya da cümlelerle varlığının belirlendiği analizdir (Büyüköztürk vd., 2012). Katılımcıların geliştirdikleri metaforların analiz edilmesi, aşağıdaki dört aşamada gerçekleştirilmiş̧ir: (1) kodlama ve ayıklama aşaması, (2) örnek metafor imgesi derleme aşaması, (3) kategori geliştirme aşaması, (4) geçerlik ve güvenirliği sağlama aşaması.

\section{Kodlama ve ayıklama aşaması:}

$\mathrm{Bu}$ aşamada katılımcılar tarafindan üretilen metaforlar arka arkaya yazılıp listelenmiştir. Listelenen metaforlar incelenmiş ve frekans sayıları ve yüzdelerine göre sıralanmıştır. Bir metaforun kullanılmadığı, birden fazla metaforun kullanıldığ 1 ve boş bırakılan çalışma kağıtları araştırmadan çıkarılmıştır. Bu aşamada her katılımcının sunduğu kâğıtta dile getirilen metafor kodlanmıştır (örneğin güneş, özgürlük, ağaç vb). Elde edilen metaforlardan geliştirilen kategoriler sınıf düzeyine göre ele alınmıştır.

\section{2. Örnek metafor imgesi derleme aşaması:}

Kağıtlar ayıklandıktan sonra, bu metaforlar tekrar sıralanmış ve ham veriler ikinci kez gözden geçirilerek her metaforu temsil eden öğrenci kompozisyonlarından birer örnek metafor ifadesi seçilmiş̧ir. Böylece, 202 metaforun her biri için onu en iyi temsil ettiği varsayılan öğrenci metafor imgelerinin derlenmesiyle birlikte bir "örnek metafor listesi" oluşturulmuştur. Seçilen bir metafor ifadesinin uzun olduğu durumlarda, katılımcıların kendi sözcükleri ve anlatım dili korunarak metaforun sadece önemli boyutları aktarılmıştır. Bir metafor imgesini kimin ürettiğine ilişkin kişisel bilgiler, söz konusu metafor ifadesinin hemen ardında yer alan parantez içinde kodlanmış, olarak verilmiştir. Araştırmacılar bu aşamada elde ettikleri verileri kuramsal çerçeveden yola çıkarak düzenlemişlerdir. Araştırmaya katılan öğretmen adayları önce sınıf düzeylerine göre gruplandırılmıştır. Daha sonra ise öğretmen adaylarına sınıf düzeylerine göre kodlar verilmiştir. Örneğin 1.sınıf Sosyal Bilgiler öğretmen aday1 S.B.Ö.A.K.1.1., $\quad$ S.B.Ö.A.E.1.2., $\quad$ S.B.Ö.A.E.1.3, ….., S.B.Ö.A.K.1.54. şeklinde kodlanmıştır. Aynı kodlamalar diğer sınıf düzeyleri içinde gerçekleştirilmiştir. 


\section{Kategori geliştirme aşaması}

$\mathrm{Bu}$ aşamada katılımcılar tarafından üretilen meaforlar ortak özelliklerine bakılarak incelenmiş ve katılımcıların metaforu nasıl kavramsallaştırıldığına bakılmıştır. Katılımcılar tarafından üretilen her metafor imgesi (1) metaforun konusu, (2) metaforun kaynağı ve (3) metaforun konusu ile kaynağı arasındaki ilişki bakımlarından analiz edilmiştir. Araştırmanın bu aşamasında veriler okunmuş ve geçerli metaforlar belirlenmiştir. Metaforlar, metaforun kaynağı ve metaforun kaynağından atfedilmesi düşünülen özellikler bakımından analiz edilerek ortak noktalar tespit edilmiştir. Ortak noktalardan hareketle kategoriler oluşturulmuştur. Araştırmada 10 farklı kategori (örneğin, aydınlatıcı ve yol gösterici olarak Atatürkçülük, gereklilik ve zorunluluk olarak Atatürkçülük gibi) elde edilmiştir.

\section{Geçerlik ve Güvenirlik}

Nitel araştırmalarda geçerlik; araştırmacıların, katılımcıların ve okuyucuların verilerin analizi sonucunda aynı şeyi anlamaları ve aynı çıkarımda bulunma durumudur (Creswell, 2016). Bu araştırmada geçerlik, elde edilen verilerin analizinin ayrıntılı bir şekilde açıklanması ve bulgulara ilişkin öğretmen adaylarının görüşlerine doğrudan yer verilerek sağlanmaya çalışılmıştır. Nitel araştırmalarda güvenirlik, elde edilen verilerin birden fazla kodlayıcı tarafından gözden geçirilmesi ve ihtilaflı durumlarda ortak bir karara varılması olarak açıklanmaktadır (Creswell, 2016). Bu araştırmada yer alan iki araştırmacı da verilerin kodlanması, sınıflara ayrılması ve kategori geliştirme sürecinde yer almıştır. Görüşlerdeki farklılıklar araştırmacıların bir araya gelmesi ve ortak bir karara varmaları ile çözüme kavuşturulmuştur. Patton (2014) bu durumu analizci üçgenlemesi olarak açıklamaktadır. Analizci üçgenlemesi, bir araştırma verilerini iki ya da daha fazla kişinin bağımsız olarak analiz etmesi ve elde edilen verilerin karşılaştırılması durumudur. Araştırmacılar bu araştırmada başlangıçta "inanç, koyun olmamak, ağaç, vatana-millete bağlılık, vatan-millet sevgisi, ileri görüşlülük ve vatanseverlik sevgisi” metaforlarının hangi kategoriye gireceği hususunda ayrışmışlardır. Ancak daha sonradan bu metaforların hangi kategoriye gireceğine ortak bir görüş dahilinde hareket ederek kategorilere yerleştirmişlerdir. Ayrıca araştırmacılar oluşturulan 3 kategorininismi konusunda da ayrışma yaşamışlardır. Bu kategoriler "herkesi kucaklayan bir unsur olarak Atatürkçülük", "insan hayatını koruyucu ve kolaylaştırıcı bir unsur olarak Atatürkçülük" ve "eşitlikunsuru olarak Atatürkçülük" kategorileridir. İki kategorinin adının aynı kalmasına diğer kategorinin isminin ise "eşitlik ve adalet unsuru olarak Atatürkçülük" olarak değiştirilmesine kanaat getirilmiştir.

\section{Bulgular}

$\mathrm{Bu}$ araştırmada alt problemler çerçevesinde bulgular yer verilmiştir. Öncelikle bütün sınıflara yer verilmiş daha sonra ise sınıflar birbirinden ayrılmıştır. Öğretmen adaylarının "Atatürkçülük" kavramına ilişkin oluşturdukları metaforlar tablolar 
halinde sunulmuş ve sınıf düzeylerine göre incelenmiştir. Kategorik olarak da ayrıştırmalara gidilmiştir.

Tablo 2'de tüm Sosyal Bilgiler öğretmen adaylarının geliştirdikleri metaforlar frekanslarına göre sıralanmıştır.

Tablo 2.

Sosyal Bilgiler Öğretmen Adaylarının “Atatürkçülük” Kavramına İlişkin Metaforlarl

\begin{tabular}{|c|c|c|c|c|c|}
\hline Metafor & $\mathbf{f}$ & $\%$ & Metafor & $\mathbf{f}$ & $\%$ \\
\hline 1.Güneş & 13 & 6,4 & 62.Aydınlanma çağı & 1 & 0,4 \\
\hline 2.Özgürlük & 8 & 3,9 & 63.Umut & 1 & 0,9 \\
\hline 3.Ağaç & 7 & 3,4 & 64.Sanat & 1 & 0,4 \\
\hline 4.Vatanseverlik & 6 & 2,9 & 65.Kural & 1 & 0,4 \\
\hline 5.Hayat & 6 & 2,9 & 66.Sevda & 1 & 0,4 \\
\hline 6. Bayrak & 5 & 1,9 & 67.İlke & 1 & 0,4 \\
\hline 7.Su & 5 & 2,4 & 68.Vatana-millete bağll1ık & 1 & 0,4 \\
\hline 8. Devrim & 4 & 2,4 & 69.Ayak izi & 1 & 0,4 \\
\hline 9.Türkiye Cumhuriyeti & 4 & 1,4 & 70.Ruh-beden ilişkisi & 1 & 0,4 \\
\hline 10.Gökyüzü & 4 & 1,9 & 71.Evrim & 1 & 0,4 \\
\hline 11. Işık & 3 & 1,9 & 72.Dünya & 1 & 0,4 \\
\hline 12.Öğretmen & 3 & 1,4 & 73.Mücadele & 1 & 0,4 \\
\hline 13.Milliyetçilik & 3 & 1,4 & 74.Galatasaray & 1 & 0,4 \\
\hline 14. Vatan & 3 & 0,9 & 75.Ev & 1 & 0,4 \\
\hline 15.Çağdaşlaşma & 3 & 0,4 & 76.Toprak ana & 1 & 0,4 \\
\hline 16. Yenilik & 3 & 0,9 & 77.Çatı & 1 & 0,4 \\
\hline 17. Ülkü & 2 & 0,4 & 78.Okul & 1 & 0,4 \\
\hline 18.İleri görüşlülük & 2 & 0,9 & 79.Anne & 1 & 0,4 \\
\hline 19.Nefes almak & 2 & 0,9 & 80.İmrenmek & 1 & 0,4 \\
\hline 20.Şah damarı & 2 & 0,9 & 81.Hayat tarzı & 1 & 0,4 \\
\hline
\end{tabular}




\begin{tabular}{|c|c|c|c|c|}
\hline 21.Kalp & 2 & 0,9 & 82.Audi A6 & 1 \\
\hline 22. Pusula & 2 & 0,4 & 83.Terazi & 1 \\
\hline 23. Kitap & 2 & 1,4 & 84.Trabzonsporlu olmak & 1 \\
\hline 24.Baba & 2 & 0,9 & 85.Çok yönlü düşünce & 1 \\
\hline 25.Birlik & 2 & 0,9 & 86.Dört mevsim & 1 \\
\hline 26.Medeniyet/Uygarlık & 2 & 0,4 & 87.Ekin & 1 \\
\hline 27.Vatan-millet sevgisi & 2 & 0,9 & 88.İlerlemecilik & 1 \\
\hline 28.Gökkuşağ1 & 2 & 0,9 & 89.Kızılelma & 1 \\
\hline 29.Binanın temeli & 2 & 0,9 & 90.Çağdaş uygarlık düzeyi & 1 \\
\hline 30.Yol & 2 & 0,9 & 91.Çiçek & 1 \\
\hline 31.Teşekkür etmek & 2 & 1,4 & 92.Gemi kaptanı & 1 \\
\hline 32. Bina & 2 & 0,9 & 93.İnsan olmak & 1 \\
\hline 33.Oksijen & 2 & 0,9 & 94.Kaynak & 1 \\
\hline 34.Cumhuriyet & 1 & 1,4 & 95.Bıçak & 1 \\
\hline 35. Aydınlık & 1 & 0,9 & 96.Düşünce sistemi & 1 \\
\hline 36.Amaç & 1 & 0,4 & 97.Türk kültürü & 1 \\
\hline 37.Sayg1 & 1 & 0,4 & 98.Sevgi & 1 \\
\hline 38.Anka kuşu & 1 & 0,4 & 99.Kutup yıldızı & 1 \\
\hline 39.İnanç & 1 & 0,4 & 100.İnsanlığı tanıma & 1 \\
\hline 40.Koyun olmamak & 1 & 0,4 & 101.Memleket & 1 \\
\hline 41.Zekâ & 1 & 0,4 & 102.Kütüphane & 1 \\
\hline 42.Egemenlik & 1 & 0,4 & 103.TÜBİTAK & 1 \\
\hline 43.Teknoloji & 1 & 0,4 & 104.Ay & 1 \\
\hline 44.Tekerlek & 1 & 0,4 & 105.Demir & 1 \\
\hline 45.Azim & 1 & 0,4 & 106.Evlat sevgisi & 1 \\
\hline 46. Y1ld1z & 1 & 0,9 & 107.Deniz mavisi & 1 \\
\hline 47.Toprak & 1 & 0,4 & 108.Tohum & 1 \\
\hline
\end{tabular}




$\begin{array}{lcclcc}\text { 48.Kalkan } & 1 & 0,4 & \text { 109.Google } & 1 & 0,4 \\ \text { 49.Bilim ve akılc1lık } & 1 & 0,4 & \text { 110.Görüşlerini benimsemek } & 1 & 0,4 \\ \text { 50.Vazgeçmemek } & 1 & 0,4 & \text { 111.Hayat sevinci } & 1 & 0,4 \\ \text { 51.Vatandaşlık } & 1 & 0,4 & \text { 112.Modernleşme } & 1 & 0,4 \\ \text { 52.Sonsuzluk } & 1 & 0,4 & \text { 113.Ay 1şı̆̆ } & 1 & 0,4 \\ \text { 53.Millet sevgisi } & 1 & 0,4 & \text { 114.Dürbün } & 1 & 0,4 \\ \text { 54.İzmir } & 1 & 0,4 & \text { 115.İdeoloji } & 1 & 0,4 \\ \text { 55.Gemi } & 1 & 0,4 & \text { 116.Akarsu } & 1 & 0,4 \\ \text { 56.Miras } & 1 & 0,4 & \text { 117.Meyve ağacı } & 1 & 0,4 \\ \text { 57.Hümanizm } & 1 & 0,4 & \text { 118.Sır } & 1 & 0,4 \\ \text { 58.İlkbahar } & 1 & 0,4 & \text { 119.Kadın hakları } & 1 & 0,4 \\ \text { 59.Hayat felsefesi } & 1 & 0,4 & \text { 120. Düşünce } & 1 & 0,4 \\ \text { 60.Bulut } & 1 & 0,4 & & & \end{array}$

Toplam

Tablo 2 incelendiğinde öğretmen adaylarının 120 farklı metafor geliştirdikleri görülmektedir. Öğretmen adaylarının bir kısmı "Atatürkçülük" kavramını güneş kavramı $(\mathrm{f}=13, \% 6,4)$ ile ilişkilendirmişlerdir. Güneş metaforunu sırasıyla en fazla özgürlük $(\mathrm{f}=8, \% 3,9)$, ağaç $(\mathrm{f}=7, \% 3,4)$, vatanseverlik $(\mathrm{f}=6, \% 2,9)$, hayat $(\mathrm{f}=6$, $\% 2,9)$, su $(\mathrm{f}=5, \% 2,4)$ ve bayrak $(\mathrm{f}=5, \% 2,4)$ metaforları izlemektedir. Öğretmen adaylarının "Atatürkçülük" kavramını bu kadar farklı ve çok sayıda metaforla ilişkilendirmesi bu kavramın ne kadar kapsamlı ve geniş bir anlama sahip olduğunu göstermektedir. Ayrıca öğretmen adaylarının farklı hayat tecrübelerine sahip olduğu düşünüldüğünde kavrama ilişkin bu kadar çok metafor geliştirmelerinin doğal bir sonuç olduğu ifade edilebilir.

Öğretmen adaylarının metaforları, metaforlara atfedilenanlambakımından araştırmacılar tarafından 10 kategoriye ayrılmıştır. Tablo 3'te "Atatürkçülük" kavramına yönelik oluşan kategoriler ve bu kategorilere ait metaforlara yer verilmektedir. 


\section{Tablo 3.}

“Atatürkçülük” Kavramı ile Ilgili Oluşan Kategoriler ve Bu Kategorilere Ait Metaforlar

\begin{tabular}{|c|c|c|c|}
\hline Kategoriler & Metaforlar & f & $\%$ \\
\hline $\begin{array}{l}\text { Aydınlatıcı ve yol gösterici } \\
\text { olarak Atatürkçülük }\end{array}$ & $\begin{array}{l}\text { Güneş (11), 1şık (5), kitap (2), pusula (2), ayak izi (1), } \\
\text { yıldız (2), aydınlık (1), ileri görüşlülük (1), inanç } \\
\text { (1),koyun olmamak (1), ağaç (1),anka kuşu (1), } \\
\text { öğretmenlik (1), gökkuşağı (1), gökyüzü (1), bilim ve } \\
\text { akılcılık (1), milliyetçilik (1), ideoloji (1), kutup yıldızı } \\
\text { (1), özgürlük (1), ay 1şı̆̆g (1), dürbün (1), devrim (1), su } \\
\text { (2), ay (1), ülkü (2), kütüphane (1), umut (1). }\end{array}$ & 47 & 23,2 \\
\hline
\end{tabular}

Vatanseverlik (2), şah damarı (2), hayat (4), nefes almak (2), kural (1), sevda (1), oksijen (1), vatana-millete bağlılık (1), ruh-beden ilişkisi (1), kalp (1), insan olmak Gereklilik ve zorunluluk (1), ilke (1), mücadele (1), evlat sevgisi (1), sevgi (1), olarak Atatürkçülük saygı (1), Türkiye Cumhuriyeti (1), su (4), toprak (1), vazgeçmemek (1), özgürlük (1), vatan-millet sevgisi (1), sir (1), bulut (1), Google (1).

\begin{tabular}{|c|c|c|c|}
\hline $\begin{array}{l}\text { İlerleme ve gelişim unsuru } \\
\text { olarak Atatürkçülük }\end{array}$ & $\begin{array}{l}\text { Su (2), çağdaşlaşma/modernleşme (2), } \\
\text { uygarlık/medeniyet (2), kızıl elma (1), çağdaş uygarlık } \\
\text { düzeyi (1), çiçek (1), gemi kaptanı (1), ileri görüşlülük } \\
\text { (1), azim (1), umut (1), tekerlek (1), ağaç (1), miras (1), } \\
\text { özgürlük (1), amaç (1), bina (1), ilerlemecilik (1), kitap } \\
\text { (1), ekin (1), akarsu (1), tohum (1). }\end{array}$ & 24 & 11,8 \\
\hline $\begin{array}{l}\text { Sevgi ve vefa bağlamında } \\
\text { Atatürkçülük }\end{array}$ & $\begin{array}{l}\text { Vatanseverlik (4), vatan (2), Galatasaray (1), Türkiye } \\
\text { Cumhuriyeti (1), gökyüzü (2), özgürlük (1), imrenmek } \\
\text { (1), yaşam tarzı (1), Audi A6 (1), vatan-millet sevgisi } \\
\text { (1), hayat felsefesi (1), hayat sevinci (1), hayat (1), } \\
\text { görüşlerini benimsemek (1), memleket (1). }\end{array}$ & 20 & 9,9 \\
\hline $\begin{array}{l}\text { Yeniliklere ve değişime açık } \\
\text { olmak olarak Atatürkçülük }\end{array}$ & $\begin{array}{l}\text { Devrim (4), yenilik (3), çağdaşlık (2), aydınlanma çă̆ } 1 \\
\text { (1), sanat (1), zekâ (1), evrim (1), dünya (1), teknoloji } \\
\text { (1), yol (1), çağdaş düşünce (1), düşünce (1), TÜBİTAK } \\
\text { (1). }\end{array}$ & 19 & 9,4 \\
\hline $\begin{array}{l}\text { Özgürlük ve bağımsızlık } \\
\text { simgesi olarak Atatürkçülük }\end{array}$ & $\begin{array}{l}\text { Bayrak (5), özgürlük (4), cumhuriyet (1), egemenlik (1), } \\
\text { teşekkür etmek (1), kalkan (1), ilkbahar (1), sonsuzluk } \\
\text { (1), İzmir (1), gökyüzü (1). }\end{array}$ & 17 & 8,4 \\
\hline Herkesi kucaklayan bir unsur & Öğretmen (2), Türkiye Cumhuriyeti (1), ev (1), çatı (1), & 13 & 6,4 \\
\hline
\end{tabular}


olarak Atatürkçülük

okul (1), ağaç (2), hümanizm (1), millet sevgisi (1),

birlik (1), deniz mavisi (1), toprak ana (1).
Güç ve kuvvet unsuru olarak Atatürkçülük milliyetçilik (1), ağaç (1), demir (1).

İnsan hayatını koruyucu ve kolaylaştırıcı bir unsur olarak Atatürkçülük

Eşitlik ve Adalet unsuru olarak Atatürkçülük
Anne (1), baba (1), oksijen (1), Türk kültürü (1), gökyüzü (1), vatandaşlık (1), yol (1), milliyetçilik (1), meyve ağacı (1).

Terazi (1), cumhuriyet (1), Trabzonsporlu olmak (1), çok yönlü düşünce (1), dört mevsim (1), insanlığı tanıma (1), kadın hakları (1).

Tablo 3 incelendiğinde öğretmen adaylarının geliştirdikleri metaforların kaynağına göre 10 farklı kategoriye ayrıldığı görülmektedir. Öğretmen adaylarının geliştirdikleri metaforlara yükledikleri anlamlar metaforu geliştirme kaynağını ortaya koymaktadır. Öğretmen adaylarının "Atatürkçülük" kavramına ilişkin geliştirdikleri metaforlardan oluşan kategorilerde kavrama ilişkin farklı özellikler vurgulanmaktadır. Öğretmen adayları en fazla "aydınlatıcı ve yol gösterici olarak Atatürkçülük" kategorisine ( $\mathrm{f}=47, \% 23,2)$ ilişkin metafor geliştirmişlerdir. Bu kategoriyi "gereklilik ve zorunluluk olarak Atatürkçülük" (f=34, \%16,8), "ilerleme ve gelişim unsuru olarak Atatürkçülük" ( $\mathrm{f}=24, \% 11,8)$ ve "Sevgi ve vefa bağlamında Atatürkçülük" (f=20, \%9,9) kategorileri izlemektedir.

\section{Aydınlatıcı ve yol gösterici olarak Atatürkçülük kategorisine ilişkin metafor örnekleri:}

S.B.Ö.A.E.1.17. "Atatürkçülük güneş gibidir. Çünkü sürekli aydınlığl hedefler."

S.B.Ö.A.K.2.30. "Atatürkçülük pusula gibidir. Çünkü asla kaybolmazsın."

S.B.Ö.A.E.3.32. "Atatürkçülük ayak izi gibidir. Çünkü takip edilmesi gerekir."

S.B.Ö.A.K.4.9. "Atatürkçülük gökyüzü gibidir. Çünkü tüm dünyayı kapsar."

Öğretmen adayları araştırmadan elde edilen bu kategoride Atatürkçülüğün yol gösterici olduğundan bahsedilmektedir. Buna göre öğretmen adaylarının Atatürkçülüğü izlenmesi ve takip edilmesi gereken bir yol ya da yöntem olarak algılamaktadırlar. Öğretmen adaylarının geliştirdikleri güneş (13), 1şık (3), kitap (2), pusula (2) gibi metaforlar buna örnek oluşturmaktadır. Bu kategoriye ilişkin sunulan örneklerde de (S.B.Ö.A.E.1.17.- $\quad$ S.B.Ö.A.K.2.30.-S.B.Ö.A.E.3.32.- 
S.B.Ö.A.K.4.9.)öğretmen adayları Atatürkçülüğü yol gösterici olarak ve izlenmesi gereken bir sistem olarak algıladıklarını ifade etmektedirler.

\section{Gereklilik ve zorunluluk olarak Atatürkçülük kategorisine ilişkin metafor örnekleri:}

S.B.Ö.A.E.1.23. “Atatürkçülük nefes almak gibidir. Çünkü onsuz yaşayamayız.”

S.B.Ö.A.E.2.2. “Atatürkçülük su gibidir. Çünkü yaşamak için ihtiyacımız olan kaynaktır."

S.B.Ö.A.E.4.21. “Atatürkçülük kalp gibidir. Çünkü kalpsiz bir vücut nasıl hayat bulamazsa Atatürkçülük olmadan da bir millet hayat bulamaz.”

Öğretmen adayları araştırmadan elde edilen bu kategoride "Atatürkçülük" kavramını toplumsal hayatın devam ettirilmesinde zorunlu ve gerekli bir unsur olarak görmektedirler. Öğretmen adaylarının geliştirdikleri vatanseverlik (2), şah damarı (2), hayat (5), nefes almak (2) gibi metaforlar "Atatürkçülük" kavramını zorunlu ve gerekli bir unsur olarak gördüklerini ortaya koyar niteliktedir. $\mathrm{Bu}$ kategoriye ilişkin sunulan örneklerde de (S.B.Ö.A.E.1.23.-S.B.Ö.A.E.2.2.S.B.Ö.A.E.4.21.) öğretmen adaylarının Atatürkçülüğe ilişkin nefes almak, su ve kalp gibi metaforlar geliştirmeleri bu kavramı zorunlu ve gerekli bir unsur olarak algıladıklarını göstermektedir.

\section{İlerleme ve gelişim unsuru olarak Atatürkçülük kategorisine ilişkin metafor örnekleri:}

S.B.Ö.A.K.1.29 "Atatürkçülük çiçek gibidir. Çünkü sürekli gelişir.”

S.B.Ö.A.K.1.46. “Atatürkçülük miras gibidir. Çünkü biz M. K. Atatürk'ün güvendiği genç nesiliz ve onun emanetini ileriye götürecek olan bizleriz."

S.B.Ö.A.K.3.40. “Atatürkçülük ilerlemecilik gibidir. Çünkü bir ulusuna yükselmesi buna bă̆lıdır.”

S.B.Ö.A.K.4.13. “Atatürkçülük kızll elma gibidir. Çünkü ulaşmamız gereken tek hedeftir."

Öğretmen adayları araştırmadan elde edilen bu kategoride "Atatürkçülük" kavramını ilerleme ve gelişim unsuru olarak görmektedirler. Öğretmen adaylarının geliştirmiş oldukları su (2), çağdaşlaşma/modernleşme (2), uygarlık (1), kızıl elma (1) ve çağdaş uygarlık düzeyi (1) gibi metaforlar "Atatürkçülük" kavramını ilerleme ve gelişim unsuru olarak algıladıklarını göstermektedir. $\mathrm{Bu}$ kategoriye ilişkin sunulan örneklerdede(S.B.Ö.A.K.1.29-S.B.Ö.A.K.1.46.-S.B.Ö.A.K.3.40.S.B.Ö.A.K.4.13.) öğretmen adaylarının çiçek, miras, ilerlemecilik ve kızıl elma gibi metaforlar geliştirmeleri ve metaforlarının kaynağında hedef ve ilerleme unsurunun bulunması "Atatürkçülük" kavramının ilerleme ve gelişim unsuru olarak algılandığını göstermektedir. 


\section{Sevgi ve vefa bağlamında Atatürkçülük kategorisine ilişkin metafor örnekleri:}

S.B.Ö.A.E.1.2. "Atatürkçülük vatanseverlik gibidir. Çünkü vatanını çok seven örnek birisidir.'

S.B.Ö.A.E.1.3. "Atatürkçülük vatanseverlik gibidir. Çünkü bu ülkeyi kuran ve kurtaran kişiyi sevmeyen vatanın sevmez.”

S.B.Ö.A.K.4.25. "Atatürkçülük memleket gibidir. Çünkü bıraktı̆̆l toprakta yaşıyoruz."

Öğretmen adayları araştırmadan elde edilen bu kategoride "Atatürkçülük" kavramını ülkeyi kuran kişiyi sevmek ve ona borçlu olmak olarak algılamaktadırlar. Öğretmen adaylarının geliştirdikleri vatanseverlik (4) ve vatan (2) gibi metaforlar bu kategori ile ilişkilendirilen başlıca metaforlardır. Bu kategoriye ilişkin sunulan örneklerde de(S.B.Ö.A.E.1.2.-S.B.Ö.A.E.1.3.-S.B.Ö.A.K.4.25.) öğretmen adaylarının Atatürkçülüğe ilişkin geliştirdikleri metaforların vatanseverlik ve memleket gibi metaforlar olması bu kavramı ülkeyi kuran kişiyi sevmek ve ona borçlu olmak olarak algıladıklarını göstermektedir.

Yeniliklere ve değişime açık olmak olarak Atatürkçülük kategorisine ilişkin metafor örnekleri:

S.B.Ö.A.K.2.4. "Atatürkçülük çağdaşlık gibidir. Çünkü kllık-klyafet olarak ve diğer yönlerden çağdaşlaştık.”

S.B.Ö.A.K.2.19. "Atatürkçülük devrim gibidir. Çünkü yeni bir düşünce sistemi ve bir başkaldırmadır."

S.B.Ö.A.E.2.21. “Atatürkçülük dünya gibidir. Çünkü yeniliği temel alır.”

S.B.Ö.A.K.3.41. "Atatürkçülük çağdaşlık gibidir. Çünkü yeniliklere açık olmayı, gelişmeyi ve ilerlemeyi öngörür.”

Araştırmadan elde edilen bu kategoride öğretmen adaylarının bir kısmı "Atatürkçülük" kavramını yeniliklere ve değişime açık olmak olarak algılamaktadırlar. Öğretmen adaylarının geliştirmiş oldukları devrim (4), yenilik (2), dünya (1) ve çağdaşlık (2) gibi metaforlar “Atatürkçülük” kavramını yenilik ve değişim ile ilişkilendiren başlıca metaforlardır. Bu kategoriye ilişkin sunulan örneklerde de(S.B.Ö.A.K.2.4.-S.B.Ö.A.K.2.19.-S.B.Ö.A.E.2.21.-S.B.Ö.A.K.3.41.) öğretmen adaylarının Atatürkçülüğe ilişkin geliştirdikleri metaforların devrim, dünya ve çağdaşlık metaforları olması bu kavramı yeniliklere ve değişime açık olmak olarak algıladıklarını ortaya koymaktadır.

Özgürlük ve bağımsızlık simgesi olarak Atatürkçülük kategorisine ilişkin metafor örnekleri: 
S.B.Ö.A.E.1.6. “Atatürkçülük bayrak gibidir. Çünkü Türkiye için olmazsa olmazdır.".

S.B.Ö.A.K.2.14. “Atatürkçülük özgürlük gibidir. Çünkü bă̆ımsızlı̆̆l ondan ögrendik."

S.B.Ö.A.E.2.20. “Atatürkçülük bayrak gibidir. Çünkü hürriyetin sembolüdür.”

S.B.Ö.A.E.3.11. “Atatürkçülük özgürlük gibidir. Çünkü güçlü devletlerin ülkemizi gasp ettikleri yıllarda yokluk içindeki yıllarda milletimize güç vermiş ve Türk olduklarını hatırlatmıştır."

Bu kategoride öğretmen adaylarının büyük bir kısmı bayrak (8) ve özgürlük (4) metaforlarını geliştirmişlerdir. Bayrak, özgürlük ve bağımsızlığın simgesi olarak bilinmektedir. $\mathrm{Bu}$ kategoriye ilişkin sunulan örneklerde de (S.B.Ö.A.E.1.6.S.B.Ö.A.K.2.14.-S.B.Ö.A.E.2.20.-S.B.Ö.A.E.3.11.)

öğretmen adaylarınıngeliştirdikleri metaforlar bu durumu destekler niteliktedir.

Herkesi kucaklayan bir unsur olarak Atatürkçülük kategorisine ilişkin metafor örnekleri:

S.B.Ö.A.K.3.45. "Atatürkçülük okul gibidir. Çünkü toplumu eğitir."

S.B.Ö.A.K.4.6. "Atatürkçülük toprak ana gibidir. Çünkü ona verilen her şeyi bă̆rina basar."

S.B.Ö.A.E.4.15. “Atatürkçülük birlik gibidir. Çünkü farklı görüşleri aynı çerçevede tutmak istemiştir."

Öğretmen adayları araştırmadan elde edilen bu kategoride “Atatürkçülük" kavramını herkesi kucaklayan bir unsur olarak algılamaktadırlar. Öğretmen adaylarının geliştirmiş oldukları öğretmen (2), Türkiye Cumhuriyeti (1), ev (1), çatı (1), okul (1), ağaç (3), hümanizm (1), millet sevgisi (1), birlik (1), deniz mavisi (1), toprak ana (1) gibi metaforlar "Atatürkçülük" kavramını herkesi kucaklayan bir unsur olarak göstermektedir. $\mathrm{Bu}$ kategoriye ilişkin sunulan örneklerde de (S.B.Ö.A.K.3.45.-S.B.Ö.A.K.4.6.- $\quad$ S.B.Ö.A.E.4.15.) öğretmen adaylarının "Atatürkçülük" kavramını okul, toprak ana ve birlik kavramları ile ilişkilendirmesi kavramın kapsayıcı ve bütünsel bir özelliği olduğunu ortaya koymaktadır.

\section{Güç ve kuvvet unsuru olarak Atatürkçülük kategorisine ilişkin metafor örnekleri:}

S.B.Ö.A.K.1.3. "Atatürkçülük Türkiye Cumhuriyeti gibidir. Çünkü Türkiye Cumhuriyeti, Atatürk ile var olmuştur."

S.B.Ö.A.K.3.35. "Atatürkçülük binanın temeli gibidir. Çünkü temel sağlam olursa her şey düzenli olur." 
Araştırmada elde edilen bu kategoride öğretmen adaylarının bir bölümü Atatürkçülüğü güç ve kuvvet unsuru olarak algılamaktadırlar. Öğretmen adaylarının geliştirmiş oldukları binanın temeli (2), bina (1), kaynak (1), bıçak (1), gemi (1), birlik (1), Türkiye Cumhuriyeti (1), baba (1), milliyetçilik (1), ağaç (1) ve demir (1) gibi metaforlar bu kategori ile ilgili başlıca metaforlardır. Bu kategoriye ilişkin sunulan örneklerde de (S.B.Ö.A.K.1.3.-S.B.Ö.A.K.3.35.) öğretmen adaylarının "Atatürkçülük" kavramını Türkiye Cumhuriyeti ve binanın temeli kavramları ile ilişkilendirmişlerdir. Bu metaforların kaynağının güç ve kuvvete yönelik olduğu görülmektedir.

\section{İnsan hayatını koruyucu ve kolaylaştırıcı bir unsur olarak Atatürkçülük kategorisine ilişkin metafor örnekleri:}

S.B.Ö.A.K.1.39. Atatürkçülük anne gibidir. Çünkü sahiplenir, düşünür, seni sen yapar."

S.B.Ö.A.K.2.16. “Atatürkçülük baba gibidir. Çünkü evini ve evlatlarını çok iyi korur."

S.B.Ö.A.K.2.33. “Atatürkçülük Türkiye Cumhuriyeti gibidir. Çünkü her kesimi içinde barındırır."

S.B.Ö.A.E.4.27. “Atatürkçülük meyve ăgacı gibidir. Çünkü bir ăgaçtaki meyve gibi topluma fayda sağlar."

Araştırmadan elde edilen bu kategoride öğretmen adaylarının bir kısmı "Atatürkçülük" kavramını insan hayatını koruyucu ve kolaylaştırıcı bir unsur olarak algılamaktadırlar. Öğretmen adaylarının geliştirmiş oldukları anne (1), baba (1), oksijen (1), Türk kültürü (1), gökyüzü (1), vatandaşl1k (1), yol (1), milliyetçilik (1) ve meyve ağacı (1) metaforları Atatürkçülük kavramını insan hayatını koruyucu ve kolaylaştırıcı bir unsur olarak Atatürkçülük kategorisinde yer alan metaforlardır. Bu kategoriye ilişkin sunulan örneklerde de(S.B.Ö.A.K.1.39.- S.B.Ö.A.K.2.16.S.B.Ö.A.K.2.33.-S.B.Ö.A.E.4.27.) "Atatürkçülük” kavramı anne, baba, Türkiye Cumhuriyeti ve meyve ağacına benzetilmektedir. $\mathrm{Bu}$ metaforlar ile korunma duygusu ve insan hayatı kolaylaştırma durumunu vurgulamaktadırlar.

Eşitlik ve adalet unsuru olarak Atatürkçülük kategorisine ilişkin metafor örnekleri:

S.B.Ö.A.K.2. 5. "Atatürkçülük terazi gibidir. Çünkü eşitlik en güçlü ilkesidir.”

S.B.Ö.A.E.3.19. “Atatürkçülük insanlı̆̆l tanıma gibidir. Çünkü herkese eşit yaklaşır."

S.B.Ö.A.K.4.1. “Atatürkçülük kadın hakları gibidir. Çünkü kadınlara seçme ve seçilme hakkı verilmiştir." 
Araştırmadan elde edilen bu kategoride öğretmen adaylarının bir kısmı “Atatürkçülük" kavramını eşitlik unsuru olarak “Atatürkçülük” olarak algılamaktadırlar. Öğretmen adaylarının geliştirdikleri terazi (1), cumhuriyet (1), Trabzonsporlu olmak (1), çok yönlü düşünce (1), dört mevsim (1), insanlığı tanıma (1) ve kadın hakları (1) gibi metaforlar "Atatürkçülük" kavramını bu kategori ile ilişkilendiren başlıca metaforlardır. Bu kategoriye ilişkin sunulan örneklerde de(S.B.Ö.A.K.2.5.-S.B.Ö.A.E.3.19.-S.B.Ö.A.K.4.1.) öğretmen adaylarının terazi, Trabzonsporlu olmak ve kadın hakları gibi metaforlar geliştirmeleri farklılıklara ve eşitliğe vurgu yapan metaforlar olarak düşünülebilir.

Tablo 4'te 1.sınıf Sosyal Bilgiler öğretmen adaylarının “Atatürkçülük” kavramına ilişkin geliştirdikleri metaforlar frekanslarına göre sıralanmaktadır.

Tablo 4 .

1.Sınıf Sosyal Bilgiler Öğretmen Adaylarının “Atatürkçülük” Kavramına İlişkin Metaforlarl

\begin{tabular}{|c|c|c|c|c|c|c|c|}
\hline Metafor & $\mathbf{K}$ & $\mathbf{E}$ & f & $\%$ & Metafor & $\mathbf{K}$ & $\mathbf{E}$ \\
\hline 1.Vatanseverlik & - & 6 & 6 & 11,1 & 21.İnanç & 1 & - \\
\hline 2.Güneş & 1 & 2 & 3 & 5,5 & 22.Gemi & - & 1 \\
\hline 3.Bayrak & 1 & 2 & 3 & 5,5 & 23.İleri görüşlülük & 1 & - \\
\hline 4.Vatan & 2 & - & 2 & 3,7 & 24.Egemenlik & 1 & - \\
\hline 5.Hayat & 1 & 1 & 2 & 3,7 & 25.Azim & 1 & - \\
\hline 6.Teşekkür etmek & 2 & - & 2 & 3,7 & 26.Birlik & 1 & - \\
\hline 7.Türkiye Cumhuriyeti & 1 & 1 & 2 & 3,7 & 27.Öğretmen & 1 & - \\
\hline 8.Gökyüzü & 2 & - & 2 & 3,7 & 28.Umut & - & 1 \\
\hline 9.Su & 2 & - & 2 & 3,7 & 29.Teknoloji & - & 1 \\
\hline 10. Anne & 1 & - & 1 & 1,8 & 30.Tekerlek & - & 1 \\
\hline 11.Sevda & - & 1 & 1 & 1,8 & 31.Vatan-millet sevgisi & 1 & - \\
\hline 12.Zekâ & - & 1 & 1 & 1,8 & 32.Ağaç & - & 1 \\
\hline 13.Kural & - & 1 & 1 & 1,8 & 33.Gökkuşağ1 & 1 & - \\
\hline 14.Çiçek & 1 & - & 1 & 1,8 & 34.Toprak & 1 & - \\
\hline 15.Dört mevsim & - & 1 & 1 & 1,8 & 35.Kalp & 1 & - \\
\hline 16. Nefes almak & - & 1 & 1 & 1,8 & 36.Kalkan & 1 & - \\
\hline
\end{tabular}




$\begin{array}{lccccl}\text { 17.Insan olmak } & 1 & - & 1 & 1,8 & \text { 37.Miras } \\ \text { 18.Çatı } & 1 & - & 1 & 1,8 & \text { 38.Baba } \\ \text { 19.Işık } & - & 1 & 1 & 1,8 & \text { 39.Binanın temeli } \\ \text { 20.Aydınlık } & - & 1 & 1 & 1,8 & \end{array}$

Toplam

Tablo 4'e göre 1.sınıf öğretmen adaylarının toplam 39 farklı metafor geliştirdiği görülmektedir. Elde edilen metaforların çoğunluğu kadın cinsiyetine sahip öğretmen adayları $(\mathrm{f}=29)$ tarafından geliştirilmiştir. Öğretmen adaylarının en çok üzerinde durdukları metaforlar sırasıyla vatanseverlik $(f=6, \% 11,1)$, güneş $(f=3, \% 5,5)$ ve bayrak (f=3, \%5,5) metaforlarıdır. Kadın öğretmen adayları "Atatürkçülük" kavramını daha çok vatan $(\mathrm{f}=2)$, teşekkür etmek $(\mathrm{f}=2)$, gökyüzü ( $\mathrm{f}=2)$ ve su $(\mathrm{f}=2)$ kavramları ile ilişkilendirmişlerdir. Erkek öğretmen adayları ise "Atatürkçülük" kavramını daha çok vatanseverlik $(\mathrm{f}=6)$, güneş $(\mathrm{f}=2)$ ve bayrak $(\mathrm{f}=2)$ kavramları ile ilişkilendirmişlerdir. Buna göre kadın ve erkek öğretmen adaylarının "Atatürkçülük" kavramına farklı anlamlar yükledikleri söylenebilir. Bunun nedeni "Atatürkçülük" anlayışının kadınlara insan hak ve özgürlükleri kapsamında tanımış olduğu özgürlükler, eşitlik ve çeşitli haklar olarak görülebilir.

Tablo 5 .

1.Sınıf Sosyal Bilgiler Öğretmen Adaylarının “Atatürkçülük” Kavramı ile İlgili Metaforlarının Kategorilere Dă̆ılımı

\begin{tabular}{|c|c|c|c|}
\hline Kategoriler & Metaforlar & f & $\%$ \\
\hline $\begin{array}{l}\text { Aydınlatıcı ve yol gösterici } \\
\text { olarak Atatürkçülük }\end{array}$ & $\begin{array}{l}\text { Güneş (4), gökyüzü (1), ışık (1), aydınlık (1), } \\
\text { inanç (1), ileri görüşlülük (1), umut (1), ağaç (1), } \\
\text { gökkuşağı (1) }\end{array}$ & 12 & 22,2 \\
\hline $\begin{array}{l}\text { Gereklilik ve zorunluluk } \\
\text { olarak Atatürkçülük }\end{array}$ & $\begin{array}{l}\text { Vatanseverlik (2), hayat (2), su (2), Türkiye } \\
\text { Cumhuriyeti (1), sevda (1), kural (1), nefes almak } \\
\text { (1), insan olmak (1), toprak (1), kalp (1) }\end{array}$ & 13 & 24 \\
\hline $\begin{array}{l}\text { Sevgi ve vefa bağlamında } \\
\text { Atatürkçülük }\end{array}$ & $\begin{array}{l}\text { Vatanseverlik (4), vatan (2), Türkiye } \\
\text { Cumhuriyeti (1), gökyüzü (1), vatan-millet } \\
\text { sevgisi (1) }\end{array}$ & 9 & 16,6 \\
\hline $\begin{array}{l}\text { Özgürlük ve bağımsızlık } \\
\text { simgesi olarak Atatürkçülük }\end{array}$ & $\begin{array}{l}\text { Bayrak (3), teşekkür etmek (1), egemenlik (1), } \\
\text { kalkan (1) }\end{array}$ & 6 & 11,1 \\
\hline İlerleme ve gelişim unsuru & Çiçek (1), azim (1), tekerlek (1), miras (1) & 4 & 7,4 \\
\hline
\end{tabular}




\begin{tabular}{|c|c|c|c|}
\hline \multicolumn{4}{|l|}{ olarak Atatürkçülük } \\
\hline $\begin{array}{l}\text { Herkesi kucaklayan bir } \\
\text { unsur olarak Atatürkçülük }\end{array}$ & Çatı (1), birlik (1), öğretmen (1) & 3 & 5,5 \\
\hline $\begin{array}{l}\text { Güç ve kuvvet unsuru olarak } \\
\text { Atatürkçülük }\end{array}$ & Gemi (1), binanın temeli (1), baba (1) & 3 & 5,5 \\
\hline $\begin{array}{l}\text { Yeniliklere ve değişime açık } \\
\text { olmak olarak Atatürkçülük }\end{array}$ & Zeka (1), teknoloji (1) & 2 & 3,7 \\
\hline $\begin{array}{l}\text { İnsan hayatını koruyucu ve } \\
\text { kolaylaştırıcı bir unsur } \\
\text { olarak Atatürkçülük }\end{array}$ & Anne (1) & 1 & 1,8 \\
\hline $\begin{array}{l}\text { Eşitlik ve adalet unsuru } \\
\text { olarak Atatürkçülük }\end{array}$ & Dört mevsim (1) & 1 & 1,8 \\
\hline Toplam & & 54 & 100 \\
\hline
\end{tabular}

Tablo 5'e göre öğretmen adaylarının tüm kategorilere göre metaforlar geliştirdikleri görülmektedir. Tablo incelendiğinde 1.sınıf öğretmen adayları en fazla "gereklilik ve zorunluluk olarak Atatürkçülük" ( $\mathrm{f}=13, \% 24)$ ve "aydınlatıcı ve yol gösterici olarak Atatürkçülük" (f=12, \%22,2) kategorilerine ilişkin metafor geliştirmişlerdir. Aşağıda öğretmen adaylarının geliştirdikleri metaforlara ilişkin örnekler yer almaktadır:

S.B.Ö.A.E.1.10. “Atatürkçülük güneş gibidir. Çünkü karanlı̆̆ı aydınlatırken ona ihtiyaç duyarız."

S.B.Ö.A.K.1.17. "Atatürkçülük anne gibidir. Çünkü sahiplenir, düşünür ve seni sen yapar.

S.B.Ö.A.K.1.22. "Atatürkçülük bayrak gibidir. Çünkü göklerde özgürce dalgalanir."

S.B.Ö.A.E.1.37. "Atatürkçülük lşık gibidir. Çünkü aydınlatıcı ve yol göstericidir."

1.sınıf öğretmen adaylarının metaforlarına ilişkin verilen örneklerde (S.B.Ö.A.E.1.10.-S.B.Ö.A.K.1.17.-S.B.Ö.A.K.1.22.- S.B.Ö.A.E.1.37.) güneş, anne, bayrak ve ışık gibi farklı bakış açıları ile geliştirilmiş metaforlar yer almaktadır. Buna göre öğretmen adaylarının "Atatürkçülük" kavramına farklı anlamlar yükledikleri söylenebilir. Ayrıca öğretmen adayları geliştirdikleri metaforları farklı sebeplere dayandırmışlardır.

Tablo 6'da 2.sınıf Sosyal Bilgiler öğretmen adaylarının "Atatürkçülük" kavramına ilişkin geliştirdikleri metaforlar frekanslarına göre sıralanmaktadır. 


\section{Tablo 6.}

\section{Sını Öğretmen Adaylarının “Atatürkçülük” Kavramına İlişkin Metaforları}

\begin{tabular}{|c|c|c|c|c|c|c|c|c|c|}
\hline Metafor & $\mathbf{K}$ & $\mathbf{E}$ & $\mathbf{f}$ & $\%$ & Metafor & $\mathbf{K}$ & $\mathbf{E}$ & f & $\%$ \\
\hline 1.Özgürlük & 3 & 1 & 4 & 7,1 & 21.Yaşam tarzı & - & 1 & 1 & 1,7 \\
\hline 2.Ăgaç & - & 3 & 3 & 5,3 & 22.Çok yönlü düşünce & - & 1 & 1 & 1,7 \\
\hline 3.Milliyetçilik & 1 & 2 & 3 & 5,3 & 23.İlke & - & 1 & 1 & 1,7 \\
\hline 4.Hayat & 1 & 1 & 2 & 3,5 & 24.Bilim ve akılcılık & - & 1 & 1 & 1,7 \\
\hline 5.Iş̧1k & 1 & 1 & 2 & 3,5 & 25.Hümanizm & 1 & - & 1 & 1,7 \\
\hline $6 . \mathrm{Su}$ & - & 2 & 2 & 3,5 & 26.Vazgeçmemek & 1 & - & 1 & 1,7 \\
\hline 7.Yenilik & 1 & 1 & 2 & 3,5 & 27.Vatandaşlık & - & 1 & 1 & 1,7 \\
\hline 8.Çağdaşlık & 1 & 1 & 2 & 3,5 & 28.İlkbahar & - & 1 & 1 & 1,7 \\
\hline 9.Pusula & 2 & - & 2 & 3,5 & 29.Sonsuzluk & 1 & - & 1 & 1,7 \\
\hline 10.Türkiye & 1 & 1 & 2 & 3,5 & 30.Hayat felsefesi & 1 & - & 1 & 1,7 \\
\hline \multicolumn{10}{|l|}{ Cumhuriyeti } \\
\hline 11.Aydınlanma çağı & - & 1 & 1 & 1,7 & 31.Hayat sevinci & 1 & - & 1 & 1,7 \\
\hline 12.Koyun olmamak & - & 1 & 1 & 1,7 & 32.İnsanlığı tanıma & 1 & - & 1 & 1,7 \\
\hline 13.Galatasaray & 1 & - & 1 & 1,7 & 33.İdeoloji & 1 & - & 1 & 1,7 \\
\hline 14.Oksijen & - & 1 & 1 & 1,7 & 34.Yol & 1 & - & 1 & 1,7 \\
\hline 15.Devrim & 1 & 1 & 1 & 1,7 & 35.Millet sevgisi & 1 & - & 1 & 1,7 \\
\hline 16.Dünya & - & 1 & 1 & 1,7 & 36.Vatan & 1 & - & 1 & 1,7 \\
\hline 17.Baba & - & 1 & 1 & 1,7 & 37.İzmir & 1 & - & 1 & 1,7 \\
\hline 18.Terazi & 1 & - & 1 & 1,7 & $\begin{array}{l}\text { 38.Görüşlerini } \\
\text { benimsemek }\end{array}$ & - & 1 & 1 & 1,7 \\
\hline 19.Cumhuriyet & - & 1 & 1 & 1,7 & 39.Amaç & - & 1 & 1 & 1,7 \\
\hline 20.İmrenmek & 1 & - & 1 & 1,7 & 40.Vatan-millet sevgisi & 1 & - & 1 & 1,7 \\
\hline Toplam & & & & & & 27 & 29 & 56 & 100 \\
\hline
\end{tabular}

2.sınıf öğretmen adayları "Atatürkçülük” kavramına ilişkin toplam 40 farklı metafor geliştirmişlerdir. Öğretmen adaylarının en çok üzerinde durdukları metaforlar sırasıyla özgürlük $(f=3, \% 7,1)$, ağaç $(f=2, \% 5,3)$ ve milliyetçilik $(f=2$, 
\%5,3) metaforlarıdır. Kadın öğretmen adayları “Atatürkçülük” kavramını en fazla özgürlük $(\mathrm{f}=3)$ ve pusula $(\mathrm{f}=2)$ metaforları ile ilişkilendirirken erkek öğretmen adayları ise ağaç ( $\mathrm{f}=3)$, milliyetçilik $(\mathrm{f}=2)$, su $(\mathrm{f}=2)$ ve yenilik $(\mathrm{f}=2)$ metaforları ile ilişkilendirmişlerdir. Buradan hareketle kadın ve erkek öğretmen adaylarının "Atatürkçülük” kavramına farklı anlamlar yükledikleri anlaşılabilir.

Tablo 7.

2.Sınıf Sosyal Bilgiler Öğretmen Adaylarının “Atatürkçülük” Kavramı ile İlgili Metaforlarının Kategorilere Dă̆ılımı

\begin{tabular}{|c|c|c|c|}
\hline Kategoriler & Metaforlar & $\mathbf{f}$ & $\%$ \\
\hline $\begin{array}{l}\text { Aydınlatıcı ve yol gösterici } \\
\text { olarak Atatürkçülük }\end{array}$ & $\begin{array}{l}\text { Işık (2), pusula (2), milliyetçilik (1), su (1), } \\
\text { koyun olmamak (1), bilim ve akılcılık (1), } \\
\text { ideoloji (1) }\end{array}$ & 9 & 16 \\
\hline $\begin{array}{l}\text { Sevgi ve vefa bağlamında } \\
\text { Atatürkçülük }\end{array}$ & $\begin{array}{l}\text { Gökyüzü (1), Galatasaray (1), imrenmek (1), } \\
\text { yaşam tarzı (1), hayat felsefesi (1), hayat sevinci } \\
\text { (1), vatan (1), görüşlerini benimsemek (1) }\end{array}$ & 8 & 14,2 \\
\hline $\begin{array}{l}\text { Özgürlük ve bağımsızlık } \\
\text { simgesi olarak Atatürkçülük }\end{array}$ & $\begin{array}{l}\text { Özgürlük (4), cumhuriyet (1), ilkbahar (1), } \\
\text { sonsuzluk (1), İzmir (1) }\end{array}$ & 8 & 14,2 \\
\hline $\begin{array}{l}\text { Yeniliklere ve değişime açık } \\
\text { olmak olarak Atatürkçülük }\end{array}$ & $\begin{array}{l}\text { Yenilik (2), çăgdaşlık (2), aydınlanma çağı (1), } \\
\text { dünya (1), devrim (1), yol (1) }\end{array}$ & 8 & 14,2 \\
\hline $\begin{array}{l}\text { Gereklilik ve zorunluluk } \\
\text { olarak Atatürkçülük }\end{array}$ & $\begin{array}{l}\text { Hayat (3), su (1), oksijen (1), ilke (1), } \\
\text { vazgeçmemek (1), vatan-millet sevgisi (1) }\end{array}$ & 7 & 12,5 \\
\hline $\begin{array}{l}\text { Herkesi kucaklayan bir } \\
\text { unsur olarak Atatürkçülük }\end{array}$ & $\begin{array}{l}\text { Ağaç (3), Türkiye Cumhuriyeti (1), hümanizm } \\
\text { (1), millet sevgisi (1) }\end{array}$ & 6 & 11,1 \\
\hline $\begin{array}{l}\text { İnsan hayatını koruyucu ve } \\
\text { kolaylaştırıcı bir unsur } \\
\text { olarak Atatürkçülük }\end{array}$ & Milliyetçilik (1), baba (1), vatandaşlık (1) & 3 & 5,3 \\
\hline $\begin{array}{l}\text { Eşitlik ve adalet unsuru } \\
\text { olarak Atatürkçülük }\end{array}$ & $\begin{array}{l}\text { Terazi (1), çok yönlü düşünce (1), insanlığ } \\
\text { tanıma (1) }\end{array}$ & 3 & 5,3 \\
\hline $\begin{array}{l}\text { Güç ve kuvvet unsuru olarak } \\
\text { Atatürkçülük }\end{array}$ & Milliyetçilik (1), Türkiye Cumhuriyeti (1) & 2 & 3,5 \\
\hline $\begin{array}{l}\text { İlerleme ve gelişim unsuru } \\
\text { olarak Atatürkçülük }\end{array}$ & Amaç (1) & 1 & 1,7 \\
\hline Toplam & & 56 & 100 \\
\hline
\end{tabular}


Tablo 7 incelendiğinde 2.sınıf öğretmen adaylarının en fazla "aydınlatıcı ve yol gösterici olarak Atatürkçülük" (f=9, \%16), "Sevgi ve vefa bağlamında Atatürkçülük" (f=8, \% 14,2), "özgürlük ve bağımsızlık simgesi olarak Atatürkçülük" $(\mathrm{f}=8, \% 14,2)$ ve "yeniliklere ve değişime açık olmak olarak Atatürkçülük"( $\mathrm{f}=8$, $\% 14,2)$ kategorilerine ilişkin metafor geliştirdikleri görülmektedir.Aşağıda öğretmen adaylarının geliştirdikleri metaforlara ilişkin örnekler yer almaktadır:

S.B.Ö.A.E.2.7. “Atatürkçülük özgürlük gibidir. Çünkü bugünkü özgürlügümüzzü ona borçluyuz."

S.B.Ö.A.E.2.19. “Atatürkçülük aydınlanma çağl gibidir. Çünkü fikirleri hep yenilikçidir."

S.B.Ö.A.E.2.31. “Atatürkçülük su gibidir. Çünkü daima ileriye akar geriye değil."

S.B.Ö.A.K.2.41. “Atatürkçülük terazi gibidir. Çünkü eşitlik en güçlü ilkesidir.”

2.sınıf öğretmen adaylarının geliştirmiş oldukları metaforlara ilişkin örneklerde (S.B.Ö.A.E.2.7.-S.B.Ö.A.E.2.19.-S.B.Ö.A.E.2.31.-S.B.Ö.A.K.2.41.) Özgürlük, aydınlanma çağı, su ve terazi gibi metaforlar yer almaktadır. Öğretmen adaylarının geliştirdikleri bu metaforların kaynağı incelendiğinde farklı sebeplerle metafor ürettikleri görülmektedir. Buna göre öğretmen adaylarının "Atatürkçülük" kavramına yönelik olarak farklı algıları olduğu söylenebilir.

Tablo 8'de 3.sınıf Sosyal Bilgiler öğretmen adaylarının “Atatürkçülük" kavramına ilişkin geliştirdikleri metaforlar frekanslarına göre sıralanmaktadır.

Tablo 8.

3.sınıf sosyal bilgiler öğretmen adaylarının "Atatürkçülük” kavramına ilişkin metaforlart

\begin{tabular}{|c|c|c|c|c|c|c|c|c|c|}
\hline Metafor & $\mathbf{K}$ & $\mathbf{E}$ & $\mathbf{F}$ & $\%$ & Metafor & $\mathbf{K}$ & $\mathbf{E}$ & f & $\%$ \\
\hline 1.Özgürlük & 2 & 1 & 3 & 5,8 & $\begin{array}{l}\text { 22.Çağdaş uygarlık } \\
\text { düzeyi }\end{array}$ & 1 & - & 1 & 1,9 \\
\hline 2.Ağaç & - & 2 & 2 & 3,9 & 23.Evrim & 1 & - & 1 & 1,9 \\
\hline 3. Hayat & 2 & - & 2 & 3,9 & 24.Yenilik & 1 & - & 1 & 1,9 \\
\hline 4.Şah damarı & - & 2 & 2 & 3,9 & 25.İleri görüşlülük & - & 1 & 1 & 1,9 \\
\hline 5.Güneş & 2 & - & 2 & 3,9 & 26.Yol & 1 & - & 1 & 1,9 \\
\hline 6.Bina & 1 & 1 & 2 & 3,9 & 27.Binanın temeli & 1 & - & 1 & 1,9 \\
\hline 7.Devrim & - & 2 & 2 & 3,9 & 28.Kutup yıldızı & - & 1 & 1 & 1,9 \\
\hline
\end{tabular}




\begin{tabular}{|c|c|c|c|c|c|c|c|c|}
\hline 8. Uygarlık/Medeniyet & 2 & - & 2 & 3,9 & 29.Nefes almak & 1 & - & 1 \\
\hline 9.Gökyüzü & 1 & - & 1 & 1,9 & 30.Modernleşme & 1 & - & 1 \\
\hline 10.Öğretmen & - & 1 & 1 & 1,9 & 31.Ay 1şı̆̆ & 1 & - & 1 \\
\hline 11.Vatana-millete bağlllık & - & 1 & 1 & 1,9 & 32.Çağdaşlaşma & 1 & - & 1 \\
\hline 12.Trabzonsporlu olmak & - & 1 & 1 & 1,9 & 33.Dürbün & - & 1 & 1 \\
\hline 13.Türk kültürü & - & 1 & 1 & 1,9 & 34.İlerlemecilik & 1 & - & 1 \\
\hline 14. Sanat & 1 & - & 1 & 1,9 & 35.Çağdaş düşünce & 1 & - & 1 \\
\hline 15.Ayak izi & - & 1 & 1 & 1,9 & 36.Kitap & 1 & - & 1 \\
\hline 16. Bıçak & 1 & - & 1 & 1,9 & 37.Aydınlık & 1 & - & 1 \\
\hline 17.Bayrak & 1 & - & 1 & 1,9 & 38.Ekin & - & 1 & 1 \\
\hline 18.Oksijen & 1 & - & 1 & 1,9 & 39.Akarsu & - & 1 & 1 \\
\hline 19.Sevgi & 1 & - & 1 & 1,9 & 40.Düşünce & 1 & - & 1 \\
\hline 20.Sayg1 & 1 & - & 1 & 1,9 & 41.Su & - & 1 & 1 \\
\hline 21.Okul & - & 1 & 1 & 1,9 & 42.Evlat sevgisi & 1 & - & 1 \\
\hline Toplam & & & & & & 30 & 21 & 51 \\
\hline
\end{tabular}

3.sınıf öğretmen adayları "Atatürkçülük" kavramına ilişkin toplam 42 farklı metafor geliştirmişlerdir. Öğretmen adaylarının en çok üzerinde durdukları metaforlar sırasıyla özgürlük $(\mathrm{f}=3, \% 5,8)$, ağaç $(\mathrm{f}=2, \% 3,9)$, hayat $(\mathrm{f}=2, \% 3,9)$, şah damarı $(\mathrm{f}=2, \% 3,9)$, güneş $(\mathrm{f}=2, \% 3,9)$, bina $(\mathrm{f}=2, \% 3,9)$, devrim $(\mathrm{f}=2, \% 3,9)$ ve uygarlık/medeniyet $(\mathrm{f}=2, \% 3,9)$ metaforlarıdır. Kadın öğretmen adayları "Atatürkçülük" kavramını en fazla özgürlük $(f=2)$, hayat $(f=2)$, güneş $(f=2)$ ve uygarlık/medeniyet $(\mathrm{f}=2)$ metaforları ile ilişkilendirmişlerdir. Erkek öğretmen adayları ise en fazla ağaç $(\mathrm{f}=2)$, şah damarı $(\mathrm{f}=2)$ ve devrim $(\mathrm{f}=2)$ metaforları üzerinde durmuşlardır. Buna göre kadın ve erkek öğretmen adaylarının “Atatürkçülük” kavramına farklı anlamlar yükledikleri görülmektedir.

Tablo 9.

3.Sınıf Sosyal Bilgiler Öğretmen Adaylarının “Atatürkçülük” Kavramı ile İlgili Metaforlarının Kategorilere Dă̆ılımı

\begin{tabular}{llll}
\hline Kategoriler & Metaforlar & f & \% \\
\hline $\begin{array}{l}\text { İlerleme ve gelişim unsuru } \\
\text { olarak Atatürkçülük }\end{array}$ & $\begin{array}{l}\text { Uygarlık (2), özgürlük (1), ağaç (1), bina (1), } \\
\text { ilerlemecilik (1), çağdaş uygarlık düzeyi (1), ileri } \\
\end{array}$ & & 23,5 \\
& görüşlülük (1), modernleşme/çağdaşlaşma (2), ekin & & \\
\hline
\end{tabular}


(1), akarsu (1)

\begin{tabular}{|c|c|c|c|}
\hline $\begin{array}{l}\text { Gereklilik ve zorunluluk } \\
\text { olarak Atatürkçülük }\end{array}$ & $\begin{array}{l}\text { Şah damarı (2), özgürlük (1), hayat (1), vatana- } \\
\text { millete bağl1lık (1), sevgi (1), saygı (1), nefes } \\
\text { almak (1), evlat sevgisi (1), su (1) }\end{array}$ & 10 & 19,6 \\
\hline $\begin{array}{l}\text { Aydınlatıcı ve yol gösterici } \\
\text { olarak Atatürkçülük }\end{array}$ & $\begin{array}{l}\text { Güneş (2), özgürlük (1), ayak izi (1), kutup yıldızı } \\
\text { (1), ay ışığı (1), dürbün (1), kitap (1), aydınlık (1) }\end{array}$ & 9 & 17,6 \\
\hline $\begin{array}{lr}\text { Yeniliklere ve } & \text { değişime } \\
\text { açı olmak } & \text { olarak } \\
\text { Atatürkçülük } & \end{array}$ & $\begin{array}{l}\text { Devrim (2), sanat (1), evrim (1), yol (1), çağdaş } \\
\text { düşünce (1), düşünce (1), yenilik (1) }\end{array}$ & 8 & 15,6 \\
\hline $\begin{array}{l}\text { Güç ve kuvvet unsuru } \\
\text { olarak Atatürkçülük }\end{array}$ & Bina (1), bıçak (1), binanın temeli (1) & 3 & 5,8 \\
\hline $\begin{array}{l}\text { Sevgi ve vefa bağlamında } \\
\text { Atatürkçülük }\end{array}$ & Hayat (2) & 2 & 3,9 \\
\hline $\begin{array}{lr}\text { Özgürlük ve } & \text { bağımsızlık } \\
\text { simgesi } & \text { olarak } \\
\text { Atatürkçülük } & \\
\end{array}$ & Bayrak (1), gökyüzü (1) & 2 & 3,9 \\
\hline $\begin{array}{l}\text { Sevgi ve vefa bağlamında } \\
\text { Atatürkçülük }\end{array}$ & Öğretmenlik (1), okul (1) & 2 & 3,9 \\
\hline $\begin{array}{l}\text { İnsan hayatını koruyucu ve } \\
\text { kolaylaştırıcı bir unsur } \\
\text { olarak Atatürkçülük }\end{array}$ & Türk kültürü (1), oksijen (1) & 2 & 3,9 \\
\hline $\begin{array}{l}\text { Eşitlik ve adalet unsuru } \\
\text { olarak Atatürkçülük }\end{array}$ & Trabzonsporlu olmak (1) & 1 & 1,8 \\
\hline Toplam & & 51 & 100 \\
\hline \multicolumn{4}{|c|}{$\begin{array}{l}\text { Tablo } 9 \text { incelendiğinde } 3 \text {.sınıf öğretmen adaylarının daha çok "ilerleme ve gelişim } \\
\text { unsuru olarak Atatürkçülük" (f=12, \%23,5), "gereklilik ve zorunluluk olarak } \\
\text { Atatürkçülük" (f=10, \%19,6) ve "aydınlatıcı ve yol gösterici olarak Atatürkçülük" } \\
\text { (f=9, \%17,6) kategorilerine ait metaforlar geliştirdikleri görülmektedir. Aşağıda } \\
\text { öğretmen adaylarının geliștirdikleri metaforlara ilişkin örnekler yer almaktadır: }\end{array}$} \\
\hline
\end{tabular}

S.B.Ö.A.K.3.11. "Atatürkçülük aydınlık gibidir. Çünkü dünya tarihinden kopmadan kendini bulabilmektir."

S.B.Ö.A.K.3.33. "Atatürkçülük devrim gibidir. Tüm tabuları yıkmış ve bu ülkeyi karanlıktan kurtarmıştır.” 
S.B.Ö.A.K.3.39. “Atatürkçülük özgürlük gibidir. Çünkü özgürlüğün temellerini atan kişi Atatürk'tür.”

S.B.Ö.A.E.3.43. “Atatürkçülük bıçak gibidir. Çünkü biledikçe keskin fikirler çıkar. ',

Tablo 10'da 4.sınıf Sosyal Bilgiler öğretmen adaylarının “Atatürkçülük" kavramına ilişkin geliştirdikleri metaforlar frekanslarına göre sıralanmaktadır.

Tablo 10 .

4. Sınıf Sosyal Bilgiler Öğretmen Adaylarının “Atatürkçülük” Kavramına İlişkin Metaforlarl

\begin{tabular}{|c|c|c|c|c|c|c|c|c|c|}
\hline Metafor & $\mathbf{K}$ & $\mathbf{E}$ & f & $\%$ & Metafor & $\mathbf{K}$ & $\mathbf{E}$ & f & $\%$ \\
\hline 1.Güneş & 6 & 2 & 8 & 19 & 17.Özgürlük/bağımsızlık & 1 & - & 1 & 2,3 \\
\hline 2.Işı1k & 1 & 1 & 2 & 4,7 & 18.Bayrak & - & 1 & 1 & 2,3 \\
\hline 3.Yıldız & 2 & - & 2 & 4,7 & 19.Gökyüzü & 1 & - & 1 & 2,3 \\
\hline 4.Ülkü & - & 2 & 2 & 4,7 & 20.Öğretmen & - & 1 & 1 & 2,3 \\
\hline 5.Gökkuşağ1 & 1 & - & 1 & 2,3 & 20.Ay & - & 1 & 1 & 2,3 \\
\hline 6.Ev & 1 & - & 1 & 2,3 & 21.Birlik & - & 1 & 1 & 2,3 \\
\hline 7.Kalp & - & 1 & 1 & 2,3 & 22.Demir & 1 & - & 1 & 2,3 \\
\hline 8.Devrim & 1 & - & 1 & 2,3 & 23.Meyve ağacı & - & 1 & 1 & 2,3 \\
\hline 9.Mücadele & - & 1 & 1 & 2,3 & 24.Sir & - & 1 & 1 & 2,3 \\
\hline 10.Kızılelma & - & 1 & 1 & 2,3 & 25.Deniz mavisi & - & 1 & 1 & 2,3 \\
\hline 11.Anka kuşu & - & 1 & 1 & 2,3 & 26.Kadın hakları & 1 & - & 1 & 2,3 \\
\hline 12.Audi A6 & 1 & - & 1 & 2,3 & 27.Tohum & - & 1 & 1 & 2,3 \\
\hline 13.Gemi kaptanı & - & 1 & 1 & 2,3 & 28.Google & 1 & - & 1 & 2,3 \\
\hline 14.Ağaç & 1 & - & 1 & 2,3 & 29.TÜBİTAK & 1 & - & 1 & 2,3 \\
\hline 15.Ruh-beden ilişkisi & - & 1 & 1 & 2,3 & 30.Su & 1 & - & 1 & 2,3 \\
\hline 16.Kitap & 1 & - & 1 & 2,3 & 31.Toprak ana & 1 & - & 1 & 2,3 \\
\hline Toplam & & & & & & 23 & 18 & 41 & 100 \\
\hline
\end{tabular}

4.sınıf öğretmen adayları "Atatürkçülük” kavramına ilişkin toplam 31 farklı metafor geliştirmişlerdir. Öğretmen adaylarının en çok üzerinde durdukları 
metaforlar sırasıyla güneş $(\mathrm{f}=8, \% 19)$, 1şık $(\mathrm{f}=2, \% 4,7), \mathrm{y} 1 \mathrm{ld}$ ız $(\mathrm{f}=2, \% 4,7)$ ve ülkü $(\mathrm{f}=2, \% 4,7)$ metaforlarıdır. Kadın öğretmen adayları "Atatürkçülük" kavramını en fazla güneş $(\mathrm{f}=6)$ ve yıldız ( $\mathrm{f}=2)$ metaforları ile ilişkilendirmişlerdir. Erkek öğretmen adayları "Atatürkçülük" kavramını en fazla güneş ( $f=2)$ ve ülkü $(\mathrm{f}=2)$ metaforları ile ilişkilendirmişlerdir. Kadın ve erkek öğretmen adaylarının güneş metaforu üzerinde durduğu görülmektedir. Ancak diğer en çok üzerinde durdukları metaforlar ise farklılaşmaktadır.

Tablo 11.

4.Sınıf Sosyal Bilgiler Öğretmen Adaylarının “Atatürkçülük” Kavramı ile İlgili Metaforlarının Kategorilere Dă̆ılımı

\begin{tabular}{|c|c|c|c|}
\hline Kategoriler & Metaforlar & $\mathbf{f}$ & $\%$ \\
\hline $\begin{array}{l}\text { Aydınlatıcı ve yol gösterici } \\
\text { olarak Atatürkçülük }\end{array}$ & $\begin{array}{l}\text { Güneş (5), 1şık (2), yıldız (1), ülkü (2), gökkuşağ } 1 \\
\text { (1), anka kuşu (1), kitap (1), ay (1), su (2) }\end{array}$ & 16 & 39 \\
\hline $\begin{array}{l}\text { Gereklilik ve zorunluluk } \\
\text { olarak Atatürkçülük }\end{array}$ & $\begin{array}{l}\text { Kalp (1), mücadele (1), ruh-beden ilişkisi (1), } \\
\text { özgürlük (1), sır (1), Google (1) }\end{array}$ & 6 & 14,6 \\
\hline $\begin{array}{l}\text { Herkesi kucaklayan bir unsur } \\
\text { olarak Atatürkçülük }\end{array}$ & $\begin{array}{l}\text { Ev (1), öğretmen (1), deniz mavisi (1), toprak } \\
\text { ana (1) }\end{array}$ & 4 & 9,7 \\
\hline $\begin{array}{l}\text { Güç ve kuvvet unsuru olarak } \\
\text { Atatürkçülük }\end{array}$ & Ağaç (2), birlik (1), demir (1) & 4 & 9,7 \\
\hline $\begin{array}{l}\text { İlerleme ve gelişim unsuru } \\
\text { olarak Atatürkçülük }\end{array}$ & Kızılelma (1), gemi kaptanı (1), tohum (1) & 3 & 7,3 \\
\hline $\begin{array}{l}\text { Sevgi ve vefa bağlamında } \\
\text { Atatürkçülük }\end{array}$ & Audi 6 (1), gökyüzü (1) & 2 & 4,8 \\
\hline $\begin{array}{l}\text { Özgürlük ve bağımsızlık } \\
\text { simgesi olarak Atatürkçülük }\end{array}$ & Bayrak (2) & 2 & 4,8 \\
\hline $\begin{array}{l}\text { Yeniliklere ve değişime açık } \\
\text { olmak olarak Atatürkçülük }\end{array}$ & Devrim (1), Tübitak (1) & 2 & 4,8 \\
\hline $\begin{array}{l}\text { İnsan hayatını koruyucu ve } \\
\text { kolaylaştırıcı bir unsur } \\
\text { olarak Atatürkçülük }\end{array}$ & Meyve ağacı (1) & 1 & 2,4 \\
\hline $\begin{array}{l}\text { Eşitlik ve adalet unsuru } \\
\text { olarak Atatürkçülük }\end{array}$ & Kadın hakları (1) & 1 & 2,4 \\
\hline Toplam & & 41 & 100 \\
\hline
\end{tabular}


Tablo 11 incelendiğinde 4.sınıf öğretmen adaylarının en fazla "aydınlatıcı ve yol gösterici olarak Atatürkçülük"(f=16, \%39) ve "gereklilik ve zorunluluk olarak Atatürkçülük”(f=6, \%14,6) kategorilerine ilişkin metafor geliştirdikleri görülmektedir. Aşağıda öğretmen adaylarının geliştirdikleri metaforlara ilişkin örnekler yer almaktadır:

S.B.Ö.A.K.4.4. "Atatürkçülük toprak ana gibidir. Çünkü ona verilen her şeyi bağrına basar."

S.B.Ö.A.K.4.25. “Atatürkçülük ay gibidir. Çünkü karanlık dünyamıza ışık verir.”

S.B.Ö.A.K.4.41. “Atatürkçülük memleket gibidir. Çünkü bıraktı̆̆ı topraklarda yaşıyoruz."

S.B.Ö.A.E.4.47. “Atatürkçülük güneş gibidir. Çünkü devletin ve insanların düşüncelerini aydınlatır."

4.sınıf öğretmen adaylarının geliştirdikleri metaforlara ilişkin verilen örneklerde (S.B.Ö.A.K.4.4.- S.B.Ö.A.K.4.25.- S.B.Ö.A.K.4.41.-S.B.Ö.A.E.4.47.) toprak ana, ay, memleket ve güneş gibi metaforlar yer almaktadır. Öğretmen adayları bu metaforları farklı sebeplerle geliştirdikleri görülmektedir.

\section{Tartışma, Sonuç ve Öneriler}

$\mathrm{Bu}$ araştırmada öğretmen adayları Atatürkçülük kavramına ilişkin 120 farklı metafor geliştirmişlerdir. Öğretmen adaylarının Atatürkçülük kavramını farklı ve çok sayıda metaforla iliş̧kilendirmesi kavramın ne kadar kapsamlı ve geniş bir anlama sahip olduğunu göstermektedir. Öğretmen adaylarının çoğunluğu Atatürkçülük kavramını güneş, özgürlük, vatanseverlik, ağaç, hayat, devrim ve su metaforları ile ilişkilendirmişlerdir. 1.sınıf öğretmen adayları 39; 2.sınıf öğretmen adayları 40; 3.sınıf öğretmen adayları 42 ve 4.sınıf öğretmen adayları 31 farklı metafor geliştirmişlerdir. Bu metaforlar çeşitli kategorilere ayrılmıştır. Tüm sınıf düzeyleri temel alınarak sırasıyla "aydınlatıcı ve yol gösterici olarak Atatürkçülük, gereklilik ve zorunluluk olarak Atatürkçülük, ilerleme ve gelişim unsuru olarak Atatürkçülük, sevgi ve vefa bağlamında Atatürkçülük, yeniliklere ve değişime açık olmak olarak Atatürkçülük ve özgürlük ve bağımsızlık simgesi olarak Atatürkçülük" kategorileri öğretmen adayları tarafından en çok metafor belirtilen kategorilerdir. 1.sınıf düzeyindekategorilere bakıldığında sırasıyla "aydınlatıcı ve yol gösterici olarak Atatürkçülük, gereklilik ve zorunluluk olarak Atatürkçülük, sevgi ve vefa bağlamında Atatürkçülük ve özgürlük ve bağımsızlık simgesi olarak Atatürkçülük" kategorileri en çok metafor üretilen kategorilerdir. 2.sınıf düzeyindekategorilere bakıldığında sırasıyla "aydınlatıcı ve yol gösterici olarak Atatürkçülük, sevgi ve vefa bağlamında Atatürkçülük, özgürlük ve bağımsızlık simgesi olarak Atatürkçülük ve yeniliklere ve değişime açık olmak olarak Atatürkçülük" en çok metafor üretilen kategorilerdir. 3.sınıf düzeyindekategorilere bakıldığında sırasıyla "ilerleme ve gelişim unsuru olarak Atatürkçülük, gereklilik ve zorunluluk olarak Atatürkçülük, 
aydınlatıcı ve yol gösterici olarak Atatürkçülük ve yeniliklere ve değişime açık olmak olarak Atatürkçülük" en çok metafor üretilen kategorilerdir. 4.sınıf düzeyinde isekategorilere bakıldığında sırasıyla "aydınlatıcı ve yol gösterici olarak Atatürkçülük, gereklilik ve zorunluluk olarak Atatürkçülük, herkesi kucaklayan bir unsur olarak Atatürkçülük ve güç ve kuvvet unsuru olarak Atatürkçülük" en çok metafor üretilen kategorilerdir.Sınıf düzeyleri arasında birbirinden farklı metaforlar geliştirildiğinden dolayı kategorilerin sıklıkları da değişmiştir. Örneğin 1., 2. ve 4.sınıflarda en çok frekansa sahip olan "aydınlatıcı ve yol gösterici olan Atatürkçülük" kategorisi iken 3.sınıflarda "ilerleme ve gelişim unsuru olarak Atatürkçülük" kategorisidir. Öğretmen adaylarının ikinci olarak belirttikleri kategoriler 1., 3. ve 4.sınıflarda "gereklilik ve zorunluluk olarak Atatürkçülük" kategorisiyken 2.sınıflarda "sevgi ve vefa borcu olarak Atatürkçülük" kategorisidir. $\mathrm{Bu}$ durum öğretmen adaylarının sınıf düzeylerine göre Atatürkçülük algılarının değiştiğini göstermektedir. Bunun nedeni adayların okudukları kitaplar, yaşadığ 1 çevre, aile, okul gibi birçok faktör ile ilgili olabilir.

Literatürde çeşitli Atatürkçülük tanımlamaları mevcuttur.Akşin (2013) Atatürk devrimi ve Atatürkçülük isimli çalışmasında Atatürkçülüğü bir aydınlanma hareketi, bir kalkınma modeli, hümanizm, ideoloji, milliyetçilik, devrimcilik, halkçılık ve devletçilik olarak sınıflandırmıştır. Literatürdeki bu çalışmadan elde edilen bulgular ile bu araştırmadan elde edilen aydınlatıcı ve yol gösterici olarak Atatürkçülük ve ilerleme ve gelişim unsuru olarak Atatürkçülük kategorilerinin benzer anlamlar içerdiği görülmektedir. Atatürkçülüğü bir devlet modeli olarak ele alan Güler (tarihsiz) Atatürkçülüğü ulus-çağdaş devlet, tam bağımsız devlet ve ulusal egemenliğe dayalı devlet olarak açıklamaktadır. $\mathrm{Bu}$ durum Atatürkçülüğün, bağımsızlığa ve ulusal egemenliğe dayandırılması sebebiyle gereklilik ve zorunluluk olarak Atatürkçülük kategorisi ile; çağdaş devlet anlayışı ile de ilerleme ve gelişim unsuru olarak Atatürkçülük kategorisi ile ilişkilendirilebilir. Ertuğrul (1988) genel olarak Atatürkçülüğü milli bir ideoloji, millileşme ve çağdaşlaşma hareketi olarak değerlendirmektedir. Atatürkçülüğün milli bir ideoloji ve millileşmeye dayandırılması gereklilik ve zorunluluk olarak Atatürkçülük kategorisi ile; çağdaşlaşmaya dayandırılması ise ilerleme ve gelişim unsuru olarak Atatürkçülük kategorisi ilişkilendirilebilir. Dinç (2008) Atatürkçülüğü yeniliğe ve gelişmişliğe açıklık ile kalkınma ve çağdaşlaşma modeli olarak görmektedir. Öksüz (2006) de Atatürkçülüğü bir çağdaşlaşma hareketi olarak ele almaktadır. Dinç (2008) ve Öksüz (2006)'ün bu bakış açıları bu araştırmada, ilerleme ve gelişim unsuru olarak Atatürkçülük kategorisi ile ilişkilendirilebilir. Dayı (2003) Atatürkçülüğün bir ihtiyaçtan doğduğunu belirtmekte; ilerlemeye ve yenileşmeye açık bir düşünce sistemi olarak ele almaktadır. Bu araştırmada bu durum gereklilik ve zorunluluk olarak Atatürkçülük ve ilerleme ve gelişim unsuru olarak Atatürkçülük kategorileri ile ilişkilendirilebilir. Bu durum literatürde Atatürkçülüğün genellikle gereklilik ve zorunluluk olarak ve bunun yanında da ilerleme ve gelişim unsuru olarak ele alındığını göstermektedir. 
Özüçetin (2005)' göre Atatürkçülük özgürlük, bağımsızlık, milliyetçilik ve yenilikve toplumun temel ihtiyaçlarına cevap veren bir ideolojidir.Korkmaz (tarihsiz) Atatürkçülüğü bir düşünce sitemi olarak açıklarken bu düşünce sitemini vatan-millet sevgisine, milli birlik ve beraberliğe, özgürlük ve bağımsızlığa, yeniliklere açı olma ve çağdaşlaşmaya, akıl, mantık ve bilime, barışa, insan sevgisi ve güven duygularına dayandırmaktadır. Yılmaz (2007) Atatürkçü düşünce sisteminin çağdaşlaşma ve çağdaş uygarlık düzeyine ulaşma ile temellerinin milli egemenlik, tam bağımsızlık, millet ve milliyetçilik kavramları üzerine kurulu olduğunu belirtmektedir. Avc1 (2013) da Atatürkçü düşünce sisteminin çağdaşlaşmaya dayandığını çağdaşlaşmanın da ancak akıl, bilim, fen, özgür düşünce ve laik bir ortam ile mümkün olduğunu belirtmiştir. Mumcu (1986) Atatürkçülüğün bir ideoloji olduğunu ifade etmekte ve bu ideolojiyi amaç, yöntem ve uyum kavramları ile ilişkilendirmektedir. Kayıran ve Yeşiltaş (2013) Atatürkçülüğü "demokratik ve pragmatik ilkeler bütünü" olarak açıklamaktadır. Atatürkçülüğün temelinde akıl ve bilim ile cumhuriyetçilik, milliyetçilik, halkçıllı, devletçilik, laiklik ve inkılâpçılık ilkeleri bulunmaktadır. Akşin (2013) Atatürk devrimi ve Atatürkçülüğü ele aldığı çalışmasında Atatürkçülüğü özgürlük, eşitlik, kardeşlik, Rönesans ve aydınlanma kelimeleriyle ilişkilendirmiş̧ir. Ertuğrul (1988) Atatürkçülüğe yaratıcılık, özgürlük, bağımsızlık, çağdaşlaşma, akıl, bilim, ideoloji, millilik, milli birlik, ve ideal kavramları ile açıklama getirmiştir. Küçükmeriç (1985) Atatürkçülüğü devrim, özgürlük, insan sevgisi, barış, birleştirici olmak, ilerici olmak, saygılı olmak, bilimsellik, çağdaşlık, gerçeklik ve çalışkanlık ile açıklamaktadır. İnan (2004) ise, Atatürkçülüğü ideoloji olarak ifade etmektedir. Bu bağlamda literatürde Atatürkçülük kavramı genel olarak özgürlük, bağımsızlık, milliyetçilik, yenilik, ideoloji, vatan-millet sevgisi, milli birlik ve beraberlik, yeniliklere açık olma, çağdaşlaşma, akıl, mantık, bilim, fen, barış, insan sevgisi, güven, milli egemenlik, millet, özgür düşünce, cumhuriyetçilik, milliyetçilik, halkçılık, devletçilik, laiklik, inkılâpçlık, eşitlik, kardeşlik, Rönesans, aydınlanma, yaratıcılık, ideal, devrim, ilerici olma, saygı, bilimsellik, gerçeklik ve çalışkanlık kavramları ile ilişkilendirilmiş̧ir. Bu araştırmada öğretmen adaylarının çoğunluğu tarafindan ifade edilen özgürlük, vatanseverlik, ve devrim kavramlarının literatürde üzerinde önemle durulduğu görülmektedir. Güneş metaforu ise literatürde yer alan aydınlanma kavramı ile ilişkilendirilebilir. Literatürde Atatürkçülük kavramının ilişkilendirildiği kavramların birçoğunun öğretmen adayları tarafından metafor olarak belirtildiği görülmektedir. Bu durum öğretmen adaylarının geliştirdikleri metaforların literatür ile desteklendiğini göstermektedir. $\mathrm{Bu}$ araştırmadan yola çıarak öğretmen adaylarının Atatürkçülüğü kısmen literatüre paralel olarak değerlendirdikleri söylenebilir. Çünkü öğretmen adayları Atatürkçülük kavramının aydınlatıcı, yol gösterici ve bir ülke için gerekli olduğunu, herkesi kucaklayan, güç ve kuvvet gerektiren bir unsur olduğunu, ilerlemeyi ve gelişmeyi hedeflediğini, özgürlük ve bağımsızlı̆̆ın simgesi olduğunu, yeniliklere ve değişime açık olduğunu, insanı temele aldığını, eşitlik ve adaleti savunduğunu belirtmişlerdir. Bunun yanında da Atatürk'ü sevmenin ve ona vefa borcu göstermenin üzerinde de durmuşlardır. 
Yukarda bahsedilen tüm durumlar sosyal bilgiler programına bakıldığında da her birinin bir değer olduğu görülmektedir. Sosyal bilgiler programı değerlerin bireylerin problemlerle başa çıabilmesinde ve eyleme geçmesinde güç kaynăg 1 olduğunu bize işaret etmektedir (MEB, 2018). Yukarda belirtilen kategorilere de bakıldığında Atatürkçülük bir güç kaynağı olarak da görülmektedir. Yalnızca Atatürkçülük kendi içerisinde birden fazla değer barındırmaktadır. Halstead \& Taylor (2000) değeri davranışlara rehberlik eden ilke ve temel inançlar ve belirli eylemlerin iyi veya arzu edilebilir olduğuna karar verilen standartlar olarak, Schwartz, Melech, Lehmann, Burgess, Haris \& Owens (2001) değeri insan hayatında yol gösterici ilkeler olarak hizmet eden öneme sahip, değişen, durumsal hedefler olarak kabul etmiştir. Faiz \&Yazıcı (2018) değer insanlara rehberlik eden temel ilkeler, bireyin gurur duyduğu ve yapmaktan hoşnut olduğu davranışlar ve bazı eylemleri, nesneleri, insanları yargılayan kriterler olarak belirtilmiştir. Bundan dolayı araştırmada varılabilecek bir sonuç da Atatürkçülük kavramının bir değer olarak görülmesi olabilir. Öğretmen adayları Atatürkçülük kavramını sevgi, saygı, özgürlük, vatanseverlik, birlik olmak gibi değerlerle ilişkilendirmişlerdir. Literatürde de benzer şekildeAtatürkçülük kavramı sıklıkla özgürlük, bağımsızlık, sevgi, saygı, barış, güven, eşitlik, bilimsellik, çalışkanlık ve vatanseverlik gibi değerlerle ilişkilendirilmiştir. Bu durum Atatürkçülük kavramının tüm bu değerleri kapsayan bir kavram olarak görüldüğünü göstermektedir. Bu bağlamda Atatürkçülük kavramı bir değerler örgüsü olarak düşünülebilir. Buradan hareketle öğretim programlarındaki değerlerin kazandırılmasında Atatürkçü anlayışın önemi daha iyi anlaşılabilir. Değerlerin öğretimi sırasında Atatürkçülük kavramından yararlanılabilir. Atatürkçülüğün, Mustafa Kemal Atatürk'ün düşünce dünyası ve fikirlerinden türediği düşünüldüğünde kavramın değerlerle ilişkilendirilmesi anlam kazanmaktadır. Literatürdeki bu çalışma bu yönüyle araştırmadan elde edilen sonucu da desteklemektedir.

Atatürkçü düşünce sistemi, yeni kurulan Türkiye Cumhuriyeti'nde insan haklarının gelişmesi yönünde önemli adımların atılmasını sağlamıştır. Kadınlara seçme ve seçilme hakkının verilmesi ve medeni kanunun kabul edilmesi insan haklarına verilen değerin arttığının en önemli göstergesidir. Bu araştırmada 1.sınıf erkek öğretmen adayları Atatürkçülüğü en fazla ağaç, milliyetçilik, su ve yenilik metaforları; 2.sınıf erkek öğretmen adayları özgürlük, ağaç ve milliyetçilik metaforları; 3.sınıf erkek öğretmen adayları ağaç, şah damarı ve devrim metaforları; 4.sınıf erkek öğretmen adayları güneş ve ülkü metaforları ile ilişkilendirmişlerdir. 1.sınıf kadın öğretmen adayları "Atatürkçülük" kavramını en fazla özgürlük ve pusula; 2.sınıf kadın öğretmen adayları özgürlük, hayat ve güneş metaforları; 3.sınıf kadın öğretmen adayları hayat ve güneş metaforları; 4.sınıf kadın öğretmen adayları güneş ve yıldız metaforları ile ilişkilendirmişlerdir. Kadın ve erkek öğretmen adaylarının üzerinde durdukları metaforlar farklılaşmaktadır. Bu farklılaşma Atatürk'ün kadına verdiği önemle açıklanabilir. Türkiye birçok batı ülkesinden önce kadınlara sosyal ve siyasal haklar tanımışıtır. Haliyle kadın öğretmen adaylarının bunu özgürlükle ilişkilendirmesi olası bir sonuçtur. $\mathrm{Bu}$ durumu destekler birçok 
literatür mevcuttur. Sağ (2001)'ın tarihsel süreç içerisinde Türk kadını ve Atatürk'ü ele aldığı çalışmasında Atatürk'ün Türk kadınlarının özgürlük (seçme-seçilme, eğitim, kamu görevi yapma vb.) ve eşitlik haklarını kazanmasını sağladığından bahsedilmektedir. Korkmaz (tarihsiz) Atatürk'ün düşünce sisteminin dayandığ 1 temel değerleri ele aldığı çalışmasında eşitlik değeri üzerinde dururken Atatürk'ün kadın erkek ayrımını ortadan kaldırdığını ve kadının toplumsal hayatta çeşitli roller kazanmasını sağladığını belirtmektedir. Erdem (2015) de çalışmasında Atatürk'ün devletçi ve eşitlikçi bir yaklaşımla kadınların çeşitli haklar kazanmasını sağladığını ifade etmektedir. Kayıran ve Yeşiltaş (2013) Atatürkçülüğün getirmiş olduğu laiklik ile kadın ve erkek eşitliğinin sağlandığını belirtmektedir. Akşin (2013) çalışmasında Atatürkçülük ile kadınların çağdaşlaşmaları yolunun açıldığından bahsetmekte, Atatürkçülük-kadın ilişkisini çağdaşlaşma olarak açıklamaktadır. Literatürde Atatürk'ün genel olarak kadınlara eşitlik firsatı tanıdığından bahsedilmektedir. $\mathrm{Bu}$ bağlamda Atatürkçülük ve kadın ilişkisinin özgürlük, eşitlik, laiklik ve çağdaşlık olarak ele alındığını söyleyebiliriz. Bu araştırmada kadın cinsiyetine sahip öğretmen adaylarının daha çok özgürlük metaforu üzerinde durduğu görülmektedir. Güneş metaforu da en çok üzerinde durdukları ikinci metafordur. Ancak güneş metaforuna ilişkin literatürde herhangi bir bulguya rastlanılmamıştır.

\section{Öneriler}

$\mathrm{Bu}$ araştırma kavramın nasıl algılandığı üzerine yapılırken elde edilen bulgulardan birisi Atatürkçülük ile ilgili eğitim bilimleri alanında yapılan uygulamalı bir çalışmanın elde edilememiş olmasıdır. Yani genellikle doküman analizi tarzında ya da Türkiye Cumhuriyeti ve Atatürkçülük ders kapsamında çalışmalar yapılmıştır. Doğrudan kavrama yönelik çalışmalar azınlıktadır. $\mathrm{Bu}$ nedenle eğitim bilimleri alanında farklı bakış açılarıyla Atatürkçülük ile ilgili çalışmalar yapılabilir.

$\mathrm{Bu}$ çalışma sosyal bilgiler öğretmen adaylarıyla yapılmıştır. Atatürkçülük kavramı üzerine farklı çalışma gruplarıyla ve karşılaştırılmalı çalışmalar gibi farklı yöntemlerle çalışmalar yapılabilir.

Atatürkçülük, içeriğine birçok anlam sığdırılan bir kavram haline gelmişsir. $\mathrm{Bu}$ yönüyle düşünüldüğünde Atatürkçülük toplumsal kanıları ve anlayışı yansıtan bir değer olarak düşünülebilir. Atatürk'ün Türk milletine ve toplumsal hayatına katkıları ders kitaplarında ve öğretim programlarında yer almaktadır. Nitekim bu araştırmadan elde edilen sonuca göre Atatürk'ün tarihi bir şahsiyet olmasının dışında Atatürkçülük düşünce sisteminde bir değer olarak algılandığı bulgusu elde edilmiştir. $\mathrm{Bu}$ nedenle Atatürkçülük kavramına bir değer olarak doğrudan çeşitli derslerin öğretim programlarında değerler başlığı altında yer verilebilir.

\section{Kaynakça}

Akçakayalığlu, C. (1989). Mîlli kültürümüzde Atatürkçülük ve bugünümüz. Ankara Üniversitesi Türk İnkllap Tarihi Enstitüsü Atatürk Yolu Dergisi, 1(03), 281-284. 
Akşin, S. (2013). Atatürk devrimi, Atatürkçülük nedir?. http://ahmetsaltik.net/arsiv/2015/04/Ataturk Devrimi_Ataturkculuk_Nedir_SIN A_AKSIN.pdfadresinden 23.04.2018 tarihinde erişilmiştir.

Atatürk, M. K. (2006). Nutuk. Ankara:Evrensel İletişim Yayınları.

Avcı, M. (2013). Atatürk ve çağdaşlaşma. Muğla Üniversitesi Sosyal Bilimler Enstitüsü Dergisi(ÍLKE) Atatürk'ün Doğumunun 125. Yılı ve Cumhuriyetimizin 83. Yılı Özel Sayısı, 162-164.

Başak, T. (2003). Bir düşünce sistemi olarak Atatürkçülük.Atatürk Dergisi, 3(3).

Büyüköztürk, Ş., Kılıç Çakmak, E., Akgün, Ö. E., Karadeniz, Ş.\& Demirel, F. (2012). Bilimsel Araştırma Yöntemleri, 3. Baskı, Ankara: Pegem Akademi Yayıncılık.

Centel, T. (2006). Prof. Dr. Zeki Başar ve Atatürkçülük kavramı. Atatürk Üniversitesi Türkiyat Araştırmaları Enstitüsü Dergisi, 12(29), 27-37.

Cihan, E. (1981). Atatürk inkılabı yorumları. İstanbul Üniversitesi Hukuk Fakültesi Mecmuasl, 45 (1-4), 119-127.

Coşgun, M. \& Zarplı, Ç. (2015). Atatürkçü demokrasinin demokratikliği tartışmaları. Akademik Bakış Dergisi, 49, 45-59.

Creswell, J. C. (2016). Nitel Araştırma Yöntemleri. M.Bütün \& S.B. Demir (Çev. Ed.), Ankara: Siyasal Kitabevi.

Dayı, S. E. (2003). Atatürkçü Düşünce Sistemi ve Nitelikleri. Atatürk Dergisi, 3(3), 247-256.

Dinç, S. (2008). Türk inkılabınında yandığı temeller ve Atatürkçülük. http://turkoloji.cu.edu.tradresinden 07.05.2018 tarihindeerişilmiştir.

Dönmez, C. (2005). Atatürk ve Cumhuriyet döneminde ortaöğretim. Selçuk Üniversitesi Sosyal Bilimler Enstitüsü Dergisi, 14, 255-268.

Dönmez, C. (2006a). Atatürk'ün eğitim ile ilgili görüş ve uygulamalarına toplu bakış. Ahi Evran Üniversitesi Kırşehir Eğitim Fakültesi Dergisi, 7(11),91-109.

Dönmez, C. (2006b). Değerler eğitiminde kahramanların kullanımınabirörnek: Mustafa Kemal Atatürk. Gazi Eğitim Fakültesi Dergisi, 26, 113-133.

Erdem, A.R. (2014). Atatürk’ün bilime verdiği önem: Bilimi ve bilimsel düşünceyi hayatta rehber edinmesi. Belgi, 8, 1033-1046.

Erdem, E. (2015). Atatürk'ün kadına ve kadın eğitimine verdiği önem. Belgi, 9(1), 1266-1277.

Ertuğrul, H. (1988). Atatürkçülük nedir?, Atatürk Dergisi, 1(2) 1-4. 
Ertuğrul, H. (1989). Atatürkçülük evrensel boyutlu bir düşünce sistemidir. Atatürk Dergisi, 1(3).

Güler, A. (tarihsiz). Bir çağdaşlaşma modeli olarak Atatürkçülük. http://turkoloji.cu.edu.tr/ATATURK/arastirmalar/guler 01.pdfadresinden 23.04.2018 tarihinde erişilmiştir.

Hic, M. (2008). Atatürkçülük, devletçilik, laiklik merkez sol ve merkez să̆ partilerin genel eğilimleri, tutumları ve yanlışları. Journal of Social Sciences 2(2), 68-97.

Halstead, J. M. \& Taylor, M. J. (2000). Learning and teaching about values: A review of recent research. Cambridge Journal of Education. 30, 169-202.

İnan, S. (2004). Atatürkçülük (Kemalizm) ve ideoloji. Liberal Düşünce, (36), 109116.

Kayadibi, F. (2006) Atatürk döneminde eğitim ve bilim alanında gelişmeler, İstanbul Üniversitesi İlahiyat Fakültesi Dergisi, 13, 1-21

Kayıran, M. ve Yeşiltaş, M. Y. (2013). Atatürkçü düşünce sistemi: Atatürkçülük (Kemalizm). Ankara Üniversitesi Türk İnklâp Tarihi Enstitüsü Atatürk Yolu Dergisi, 51, 579-615.

Keskin, M. (2004). Yeni bir dünya görüşü olarak Atatürkçülük, Sosyal Bilimler Enstitüsü Dergisi, 17(2), 1-8.

Korkmaz, Z. (tarihsiz). Atatürkçü düşünce sisteminin dayandığı değerler. www.ayk.gov.tradresinden 21.04.2018 tarihinde erişilmiştir.

Kocatürk, U. (1988). Gençlik ve Atatürkçülük. Atatürk Dergisi, 1(2), 5-13.

Küçükmeriç, Y. (1985). Atatürkçülük nedir, ne değildir?, Eğitim ve Bilim, egitimvebilim.ted.org.tradresinden 23.04.2018 tarihinde erişilmiştir.

Milli Ĕ̆itim Bakanlığı, (2018). Sosyal bilgiler dersi ögretim programı. Ankara.

Mumcu, A. (1986). Atatürkçü Düşünce Sisteminde Milli Birliğin Yeri, 10 Kasım 1986 Atatürk Kültür, Dil ve Tarih Yüksek Kurumu Atatürk’ü Anma Töreni, http://www.atam.gov.tradresinden 21.04.2018 tarihinde erişilmiştir.

Öksüz, H. (2006). Atatürkçülük ve küreselleşme sürecinde Türkiye. Afyon Kocatepe Üniversitesi Sosyal Bilimler Dergisi, 8(3), 81-92.

Özüçetin, Y. (2005). Atatürkçü Düşünce Sistemi. Gazi Üniversitesi Kırşehir Eğitim Fakültesi, 6(1), 59- 65. 
Patton, M. Q. (2014). Nitel araştırma ve değerlendirme yöntemleri. Mesut Bütün, Selçuk Beşir Demir (Çev. Ed.), 3. Baskıdan Çeviri, Ankara: Pegem Akademi Yayıncilik.

Polat, İ. (1989). Atatürk ve milli eğitim. Ankara Üniversitesi Türk İnkllap Tarihi Enstitüsü Atatürk Yolu Dergisi, l(03).

Sağ, V. (2001).Tarihsel süreç içerisinde Türk kadını ve Atatürk. C. Ü. İktisadi ve İdari Bilimler Dergisi, 2(1), 9-23.

Schwartz, S., Melech, H., Lehmann G., Burgess, A., Haris M. \& Owens V. (2001). Extending the cross-cultural validity of the theory of basic human values with a different method of measurement. Journal of Cross-Cultural Psychology, 32, 519-542.

Yılmaz, S. (2007). Atatürkçü düşünce sistemi ve Avrupa birliği değerleri. Sosyal Bilimler Dergisi, 1 (1), 108- 152.

\section{Extended Abstract}

The loss of the First World War of the Ottoman Empire ensured that the foundations of a new Turkish State were laid as well as the end of the Ottoman Empire, which had been ruling for centuries. Mustafa Kemal Atatürk has won the war of independence for the Turkish nation with it ssuperior warfare, sharp intelligence and courage. Thus, the Republic of Turkey, national, independent and has taken it splace in history as a unitary state. After the Turkish nation won the war of independence, a series of revolutions were needed. Mustafa Kemal Atatürk's reforms and innovations based on intelligence, science and philosophy in order to attain the level of contemporary civilizations have caused the concept of Ataturkism to be born. The way and methods that Atatürk followed these revolutions without being passed on to are called Ataturkism.

Although Ataturkism was born as a necessity and obligation at the beginning, it has become a philosophy, thought or ideology in the ongoing time frame. As a result, Ataturkism has become a concept extending from the past to the present day and utilized in all areas of social life. Atatürkism is the symbol of independence and freedom, the forerunner of democracy and equality, a humanist, peaceful, national and universal value that is based on reason and science. The victory of the Turkish people in the war of independence is an indication of the libertarian and independent character of Ataturkism. The equality of all the people in all spheres of social life, especially the rights given to women, shows that Ataturkism is a democratic and egalitarian structure. The revolutions based on the reason and science of the revolutions reveal the scientific side of Ataturkism. The fact that Ataturkism is the basis of human love and that providing peace and trust is important fortheprosperity of social life shows the humanistic and peaceful direction of Ataturkism. The best 
example to show that Atatürkist thinker is national is the establishment of a national Turkish state.

Therefore, the social studies teacher candidates metaphor about attitudes are important. The aim of this research is to find out how the social studies teacher candidates perceive the metaphorical perceptions of Ataturkism. The main point of the research is to contribute to the literature on the concept of Ataturkism. The following answers we researched:

- What are the perceptions of Social Studies teacher candidates regarding the concept of "Ataturkism"?

Phenomenology design was used in the research. The working group of the research is constituted by the teacher candidates who are studying in the Social Studies Teacher Undergraduate Program of a state university during the fall semester of the 2017-2018 academic year. A maximum diversity sample was used from the objective sampling types in the study. As a means of collecting data in the research, teacher candidates are asked to complete the statement "Ataturkism... is like. Because ..."

The data obtained in the research were analyzed by content analysis. Metaphores developed by prospective teachers are categorized by researchers.

In this research prospective teachers have developed 120 different metaphors about the concept of Ataturkism. The majority of the teacher candidates have associated the concept of Ataturkism with the metaphors of sun, freedom, patriotism, tree, life, revolution and water. Teacher candidates most developed metaphorfor "Ataturkism as an enlightening and guiding principle", "Ataturkism as obligation and necessity", "Ataturkism as an element of progress and development" and "Ataturkism as love and debt to the person who founded the country".

The majority of prospective teachers related the concept of Atatürkism to the metaphors of sun, freedom, patriotism, tree, life, revolution and water. 1st grade preservice teachers 39; Second grade teacher candidates 40; 3rd grade pre-service teachers 42; Fourth grade teacher candidates developed 31 different metaphors.Based on the all grades, respectively Atatürkism as an enlightening and guiding, Atatürkism as a necessity and obligation, Atatürkism as an element of progress and development, Atatürkism in the context of love and loyalty, Atatürkismbeing open to innovation and change and Atatürkism as the symbol of freedom and independence are the categories that most metaphors are mentioned. In the freshmen class, respectively Atatürkism as an enlightening and guiding, Atatürkism as a necessity and obligation, Atatürkism in the context of love and loyalty and and Kemalism as the symbol of freedom and independence are the categories that most metaphors are mentioned. In the sophomore class, Atatürkism as an enlightening and guiding, Atatürkism in the context of love and loyalty, Kemalism as the symbol of freedom, Atatürkism being open to innovation and 
change are the categories that most metaphors are mentioned. In the junior class, respectively, Atatürkism as an element of progress and development, Atatürkism as a necessity and obligation, Atatürkism as an enlightening and guiding and Atatürkism being open to innovation and change are the categories that most metaphors are mentioned. In the senior class, respectively, Atatürkism as an enlightening and guiding, Atatürkism as a necessity and obligation, Atatürkism as an element embracing everyone and Atatürkism as an element of strength and power are the categories that most metaphors are mentioned.

The fact that the teacher candidates associate the concept of Ataturkism with many different and different metaphors shows how comprehensive and broad the concept is. Teacher candidates have associated the concept of Ataturkism with values such as love, respect, freedom, patriotism, unity. In the literature, the concept of Ataturkism is often associated with values such as freedom, independence, love, respect, peace, trust, equality, scientificness, diligence and patriotism. This shows that the concept of Ataturkism is seen as a concept including all these values. In this context, the concept of Ataturkism can be considered as a braid of values.

In the study, it is seen that the teacher candidates developed different metaphors according to gender. It is mentioned in the literature that Atatürk generally recognized the possibility of equality for women. In this context, we can say that Ataturkism and women's relations are treated as freedom, equality, secularism and modernity. In this research, it is seen that female candidates with a gender tendency are more concerned with the metaphor of freedom. These views of the teacher candidates support there forms that Atatürk made towards women. 